\title{
Predicting enteric methane emission of dairy cows with milk Fourier-transform infrared spectra and gas chromatography-based milk fatty acid profiles
}

\author{
S. van Gastelen, ${ }^{*} \dagger^{1}$ H. Mollenhorst,$\ddagger^{2}$ E. C. Antunes-Fernandes, ${ }^{\star} \S^{3}$ K. A. Hettinga, $\S$ G. G. van Burgsteden, $\ddagger^{4}$ \\ J. Dijkstra, † and J. L. W. Rademaker $\ddagger^{5}$ \\ ${ }^{*}$ Top Institute Food and Nutrition, PO Box 557, 6700 AN Wageningen, the Netherlands \\ †Animal Nutrition Group, Wageningen University \& Research, PO Box 338, $6700 \mathrm{AH}$ Wageningen, the Netherlands \\ †Qlip B.V., PO Box 119, 7200 AC Zutphen, the Netherlands \\ §Food Quality and Design Group, Wageningen University \& Research, PO Box 17, $6700 \mathrm{AH}$ Wageningen, the Netherlands
}

\begin{abstract}
The objective of the present study was to compare the prediction potential of milk Fourier-transform infrared spectroscopy (FTIR) for $\mathrm{CH}_{4}$ emissions of dairy cows with that of gas chromatography (GC)-based milk fatty acids (MFA). Data from 9 experiments with lactating Holstein-Friesian cows, with a total of 30 dietary treatments and 218 observations, were used. Methane emissions were measured for 3 consecutive days in climate respiration chambers and expressed as production $(\mathrm{g} / \mathrm{d})$, yield $(\mathrm{g} / \mathrm{kg}$ of dry matter intake; $\mathrm{DMI})$, and intensity $(\mathrm{g} / \mathrm{kg}$ of fat- and protein-corrected milk; FPCM). Dry matter intake was $16.3 \pm 2.18 \mathrm{~kg} / \mathrm{d}$ (mean \pm standard deviation), FPCM yield was $25.9 \pm$ $5.06 \mathrm{~kg} / \mathrm{d}, \mathrm{CH}_{4}$ production was $366 \pm 53.9 \mathrm{~g} / \mathrm{d}, \mathrm{CH}_{4}$ yield was $22.5 \pm 2.10 \mathrm{~g} / \mathrm{kg}$ of DMI, and $\mathrm{CH}_{4}$ intensity was $14.4 \pm 2.58 \mathrm{~g} / \mathrm{kg}$ of FPCM. Milk was sampled during the same days and analyzed by GC and by FTIR. Multivariate GC-determined MFA-based and FTIR-based $\mathrm{CH}_{4}$ prediction models were developed, and subsequently, the final $\mathrm{CH}_{4}$ prediction models were evaluated with root mean squared error of prediction and concordance correlation coefficient analysis. Further, we performed a random 10-fold cross validation to calculate the performance parameters of the models (e.g., the coefficient of determination of cross
\end{abstract}

Received April 20, 2017.

Accepted February 9, 2018

${ }^{1}$ Corresponding author: sanne.vangastelen@wur.nl

${ }^{2}$ Current address: Animal Breeding and Genomics Group, Wageningen University \& Research, PO Box 338, 6700 AH Wageningen, the Netherlands.

${ }^{3}$ Current address: KeyToxicology, Yalelaan 104, 3584 CM Utrecht, the Netherlands.

${ }^{4}$ Current address: CRV B.V., PO Box 454, 6800 AL Arnhem, the Netherlands.

${ }^{5}$ Current address: Nutrition Innovation Center Ruminants, ForFarmers N.V., PO Box 91, 7240 AB Lochem, the Netherlands. validation). The final GC-determined MFA-based $\mathrm{CH}_{4}$ prediction models estimate $\mathrm{CH}_{4}$ production, yield, and intensity with a root mean squared error of prediction of $35.7 \mathrm{~g} / \mathrm{d}, 1.6 \mathrm{~g} / \mathrm{kg}$ of DMI, and $1.6 \mathrm{~g} / \mathrm{kg}$ of FPCM and with a concordance correlation coefficient of 0.72 , 0.59 , and 0.77 , respectively. The final FTIR-based $\mathrm{CH}_{4}$ prediction models estimate $\mathrm{CH}_{4}$ production, yield, and intensity with a root mean squared error of prediction of $43.2 \mathrm{~g} / \mathrm{d}, 1.9 \mathrm{~g} / \mathrm{kg}$ of DMI, and $1.7 \mathrm{~g} / \mathrm{kg}$ of FPCM and with a concordance correlation coefficient of 0.52 , 0.40 , and 0.72 , respectively. The GC-determined MFAbased prediction models described a greater part of the observed variation in $\mathrm{CH}_{4}$ emission than did the FTIRbased models. The cross validation results indicate that all $\mathrm{CH}_{4}$ prediction models (both GC-determined MFA-based and FTIR-based models) are robust; the difference between the coefficient of determination and the coefficient of determination of cross validation ranged from 0.01 to 0.07 . The results indicate that GCdetermined MFA have a greater potential than FTIR spectra to estimate $\mathrm{CH}_{4}$ production, yield, and intensity. Both techniques hold potential but may not yet be ready to predict $\mathrm{CH}_{4}$ emission of dairy cows in practice. Additional $\mathrm{CH}_{4}$ measurements are needed to improve the accuracy and robustness of GC-determined MFA and FTIR spectra for $\mathrm{CH}_{4}$ prediction.

Key words: dairy cow, enteric methane production, milk fatty acid concentration, milk Fourier-transform infrared spectroscopy

\section{INTRODUCTION}

Enteric $\mathrm{CH}_{4}$ is produced in the gastrointestinal tract of livestock, mainly ruminants, and composes $\sim 40 \%$ of global $\mathrm{CH}_{4}$ emissions (Gerber et al., 2013). Enteric $\mathrm{CH}_{4}$ is one of the main targets of mitigation strategies in the dairy cattle sector (Knapp et al., 2014). Quantification of $\mathrm{CH}_{4}$ emission is thus important. Several in vivo $\mathrm{CH}_{4}$ measurement techniques have been developed 
but are not suitable for precise and accurate large-scale measurements (Hammond et al., 2016). Cost-effective, efficient, robust, and fast $\mathrm{CH}_{4}$ measurement techniques applicable on a large scale to estimate $\mathrm{CH}_{4}$ emission of individual dairy cows are required. Therefore, identifying proxies (i.e., indicators or indirect traits related to $\mathrm{CH}_{4}$ emission) might serve as a good alternative (Negussie et al., 2017).

Milk fatty acid (MFA) profiles have been suggested as a proxy to estimate $\mathrm{CH}_{4}$ emission in dairy cattle, and many studies have evaluated this proposed relationship between MFA concentrations and $\mathrm{CH}_{4}$ emission (e.g., Chilliard et al., 2009; Mohammed et al., 2011; Rico et al., 2016). However, the GC procedure required to obtain the MFA profiles is time consuming, labor intensive, and requires expensive instruments and trained personnel (Capuano et al., 2014) and is, therefore, unsuitable for large-scale measurements. Fourier-transform infrared spectroscopy (FTIR), on the other hand, is a rapid, cost-effective, and high-throughput technique. Currently, major milk components such as fat, protein, lactose, and urea are routinely measured with FTIR by milk recording organizations. Diverse milk phenotypes can be estimated by FTIR, as illustrated by De Marchi et al. (2014), including MFA composition (e.g., Rutten et al., 2009; Soyeurt et al., 2011), milk protein composition (Bonfatti et al., 2011), technological properties of milk (DeMarchi et al., 2009), and cow health and energy status (van Knegsel et al., 2010; McParland et al., 2011).

Dehareng et al. (2012) and Vanlierde et al. (2015) used FTIR to predict $\mathrm{CH}_{4}$ emission of dairy cattle. The reported prediction accuracy of the models developed for $\mathrm{CH}_{4}$ emission was high in both studies, with a cross-validated coefficient of determination ranging from 0.68 to 0.79 . However, the $\mathrm{CH}_{4}$ predictions of Dehareng et al. (2012) at different stages of lactation were not biologically meaningful, whereas Vanlierde et al. (2015) demonstrated that a lactation stage-dependent $\mathrm{CH}_{4}$ prediction model was more robust and biologically more meaningful. The $\mathrm{CH}_{4}$ prediction potential of FTIR spectra seems moderate (reviewed by van Gastelen and Dijkstra, 2016), based on experiments only using the $\mathrm{SF}_{6}$-tracer technique to measure $\mathrm{CH}_{4}$ emission. More recently, Shetty et al. (2017) demonstrated low prediction accuracy (coefficient of determination for validation being 0.13) for $\mathrm{CH}_{4}$ emission (in L/d) when models were obtained using FTIR spectra and $\mathrm{CH}_{4}$ emission measured by the sniffer method in automated milking stations. To date, no research has assessed the $\mathrm{CH}_{4}$ prediction potential of milk FTIR spectra for $\mathrm{CH}_{4}$ data obtained in climate respiration chambers and for all 3 units of $\mathrm{CH}_{4}$ emission; namely, $\mathrm{CH}_{4}$ production (in $\mathrm{g} / \mathrm{d}$ ), $\mathrm{CH}_{4}$ yield (in $\mathrm{g} / \mathrm{kg}$ of DMI), and $\mathrm{CH}_{4}$ intensity (in $\mathrm{g} / \mathrm{kg}$ of fat- and protein-corrected milk; FPCM). The objective of the present study was to compare the prediction potential for $\mathrm{CH}_{4}$ production, yield, and intensity of milk FTIR spectra with that of the GCdetermined MFA profile, using $\mathrm{CH}_{4}$ data obtained in climate respiration chambers.

\section{MATERIALS AND METHODS}

\section{Data Collection}

Data from 9 studies, designed as randomized block experiments, from Wageningen University \& Research (Wageningen, the Netherlands) were used (Table 1). The experiments were conducted in accordance with Dutch law and approved by the Animal Care and Use Committee of Wageningen University \& Research. The 9 studies represented 30 dietary treatments and 218 individual observations from lactating Holstein-Friesian cows. The data set included multiple observations from a small number of dairy cows (218 individual observations from 189 unique dairy cows). We consider these particular observations as unique and not as repeated measurements, because of the large differences in conditions between the observations of the same dairy cows (i.e., different experiment, different dietary treatment, different parity, and different lactation stage). The experimental setup was similar for all experiments. After an adaptation period of $12 \mathrm{~d}$, cows were housed individually in open-circuit, indirect climate respiration chambers (described by van Gastelen et al., 2015) for a 5-d period to determine $\mathrm{CH}_{4}$ emission (expressed as production, yield, and intensity). Diets were fed twice daily, and intake was restricted to $95 \%$ of the voluntarily DMI of the cow consuming the least within a block.

Cows were milked twice daily, and water was freely available during the entire experiment. While cows were housed in the climate respiration chambers, milk yield was recorded and representative milk samples (i.e., $5 \mathrm{~g} / \mathrm{kg}$ of milk production from each cow) were collected at each milking according to van Gastelen et al. (2015). These milk samples were pooled per period and cow and subsequently analyzed for MFA composition (g/100 g of fatty acids) using GC as described by van Gastelen et al. (2015). The pooled milk samples were also analyzed in the laboratory of Qlip B.V. (Zutphen, the Netherlands) to determine the content of fat, protein, and lactose according to regular test-day procedures using MilkoScan FT 6000 equipment with diamond cuvettes (Foss Analytical A/S, Hillerød, Denmark) using the manufacturer supplied basic calibra- 
tion models in conformity with ISO 9622 (International Organization for Standardization, 2013). The applied reference methods were ISO 1211 (International Organization for Standardization, 2010) for fat, ISO 8968-1 (International Organization for Standardization, 2014) for total protein, and an HPLC method based on ISO 22662 (International Organization for Standardization, 2007) for lactose. The FTIR absorption spectra consisted of 1,060 infrared frequencies (wavenumbers) representing infrared light absorption through the milk samples ranging from 925 to $5,008 \mathrm{~cm}^{-1}$.

\section{Statistical Analyses}

Model Development: GC-Determined MFA. Multivariate models were developed using a stepwise procedure (PROC GLMSELECT of SAS; SAS Institute Inc., Cary, $\mathrm{NC}$, version 9.2) with $\mathrm{CH}_{4}$ emission (i.e., production, yield, and intensity) as the independent variable and stepwise selection of only GC-determined MFA (g/100 g total fatty acids). The significance level for a GC-determined MFA to enter or stay in the model was 0.01 and 0.05 , respectively. The final models were selected based on the minimum Akaike's information criterion statistic. The selected models were evaluated in PROC REG in terms of multicollinearity (variation inflation factor $>10$ ), but no multicollinearity was observed.

Model Development: FTIR. Prediction models for $\mathrm{CH}_{4}$ production, yield, and intensity were developed only on preprocessed data of selected wavenumbers as linear regression models using partial least squares calculated with the SIMPLS algorithm of the PLS toolbox (Eigenvector Research Inc., Manson, WA). In the partial least squares method, spectroscopic data were reduced to a set of orthogonal, uncorrelated components (i.e., latent variables; LV). Selected wavenumbers $(\mathrm{n}=218)$ were in the ranges 964 to $1,581 \mathrm{~cm}^{-1}, 1,715$ to $1,773 \mathrm{~cm}^{-1}$, and 2,814 to $2,968 \mathrm{~cm}^{-1}$. These wavenumbers were selected because these contain valuable information on milk composition and are thus most relevant for milk analysis (Capuano et al., 2014). Additionally, parts of the infrared spectrum that are disturbed by high water absorption were omitted, because these can interfere with the quantification of other major milk components (Capuano et al., 2014). The selected wavenumbers were preprocessed by applying the Savitzky-Golay (Savitzky and Golay, 1964), first derivative with polynomial order 2 and window width 7 , and subsequently mean centered.

Table 1. Data sources and characteristics of included studies

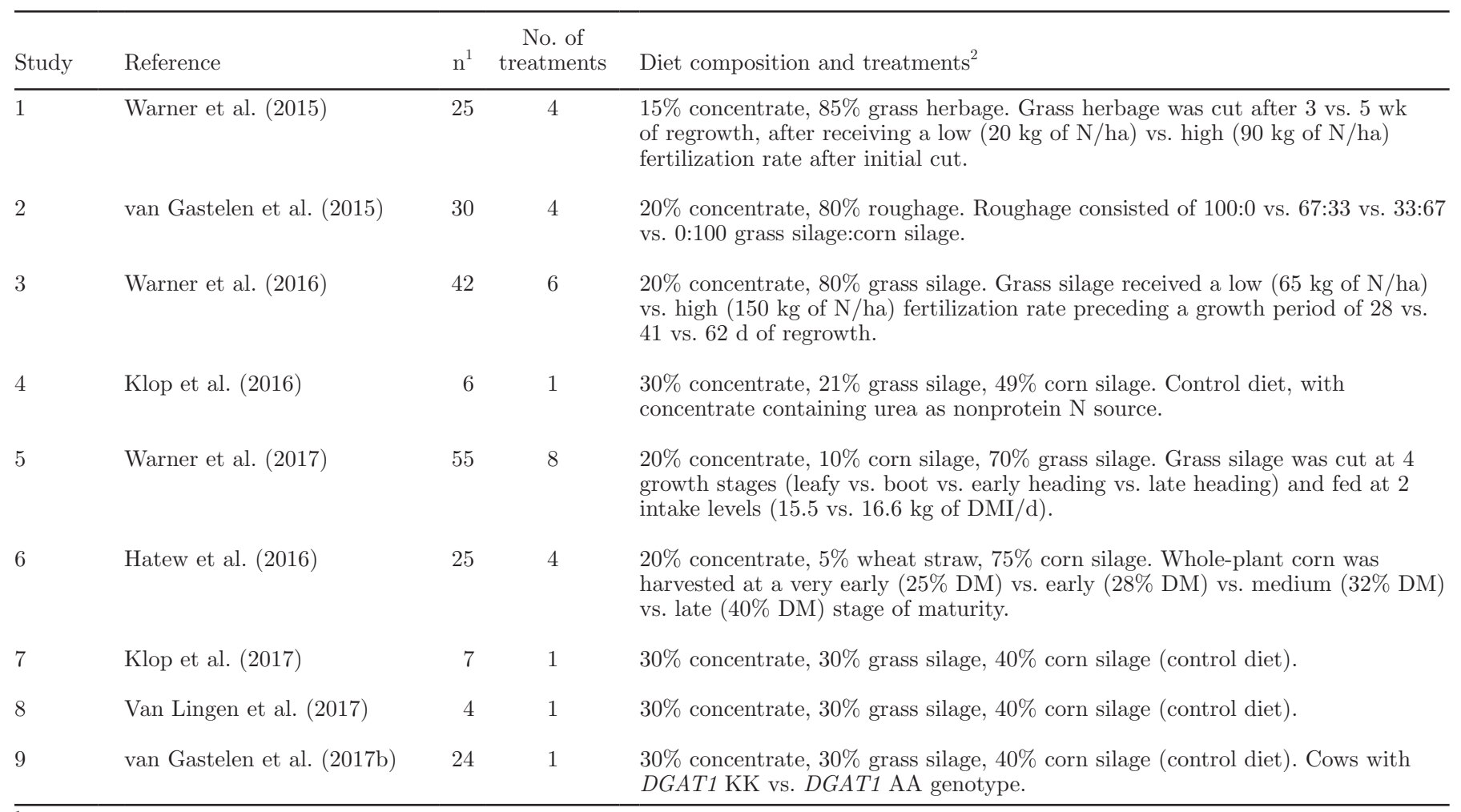

\footnotetext{
${ }^{1}$ The total number of observations, which equals the number of dairy cows, used for the present study.
}

${ }^{2}$ Proportion (\%) on DM basis. 
Model Evaluation. All $\mathrm{CH}_{4}$ prediction models, GCdetermined MFA-based and FTIR-based models, were evaluated using 2 methods. First, the mean squared error of prediction (MSEP) was calculated as

$$
\operatorname{MSEP}=\sum_{i=1}^{n}\left(O_{i}-P_{i}\right)^{2} / n,
$$

where $n$ is the total number of observations, $O_{i}$ is the observed value, and $P_{i}$ is the predicted value. The square root of the mean squared error of prediction (RMSEP) gives an estimate of the overall error of prediction and is expressed as percentage of the observed mean or expressed in grams per day, grams per kilogram of DMI, and grams per kilogram of $\mathrm{FPCM}$ for $\mathrm{CH}_{4}$ production, yield, and intensity, respectively. Second, concordance correlation coefficient analysis (CCC; Lin, 1989) was performed, where CCC is calculated as

$$
\mathrm{CCC}=r \times C_{b},
$$

where $r$ is the correlation coefficient providing a measure of precision and $C_{b}$ is a bias correction factor providing a measure of accuracy. The $C_{b}$ variable is calculated as

$$
C_{b}=2 /\left[\left(v+1 / v+\mu^{2}\right)^{\prime}\right]
$$

where

$$
\begin{gathered}
v=S_{\mathrm{o}} / S_{\mathrm{p}}, \\
\mu=\frac{\bar{O}-\bar{P}}{\left(S_{\mathrm{o}} \times S_{\mathrm{p}}\right)^{0.5}},
\end{gathered}
$$

where $v$ provides a measure of scale shift, $\mu$ provides a measure of location shift, $S_{\mathrm{o}}$ and $S_{\mathrm{p}}$ are the observed and predicted standard deviations, and $\bar{O}$ and $\bar{P}$ are the observed and predicted means. A CCC of 0.20 or less indicates poor predictive ability, between 0.21 and 0.40 indicates fair predictive ability, between 0.41 and 0.60 indicates moderate predictive ability, between 0.61 and 0.80 indicates substantial predictive ability, and between 0.81 and 1.00 indicates accurate predictive ability (Altman, 1997). Furthermore, the predictive power of the calibration was evaluated through the ratio of performance to deviation (RPD) statistic, which is the ratio of the standard deviation of the original data to the standard error of cross validation (Dehareng et al., 2012). The RPD values are preferably as high as possible; RPD values between 5 and 10 are adequate for quality control and process control and are potentially suitable for application (Williams, 2014). Additionally,
PROC CORR in SAS was used to determine the Pearson correlation between the MFA-predicted $\mathrm{CH}_{4}$ emissions and the FTIR-predicted $\mathrm{CH}_{4}$ emissions.

Cross Validation MFA and FTIR. To calculate the models performance parameters [i.e., root mean squared error of cross validation (RMSECV) and the coefficient of determination of cross validation $\left(\mathbf{R}^{2} \mathbf{C V}\right)$ ], we performed a random cross validation with 10 splits and 10 iterations as recommended by Rodriguez et al. (2010) for all MFA- and FTIR-based $\mathrm{CH}_{4}$ prediction models. For each iteration, a model was developed as described above using 9 splits of the data set, and the selected model was subsequently evaluated as described above on the remaining part of the data set (i.e., 1 split). With this approach, all observations were used for both calibration and validation, and each observation was used for validation exactly once. The cross validation performance values represent the average of the 10-fold cross validation.

This random 10-fold cross validation was also used for selection of the number of LV for the FTIR-based $\mathrm{CH}_{4}$ prediction models. The selected number of $\mathrm{LV}$ for the final models was based on the suggestion by PLS toolbox (Eigenvector Research Inc.) and visual assessment of the graphs of the root mean squared error of calculation and RMSECV against the number of LV. The number of LV before the RMSECV starts increasing or the RMSECV starts deviating considerably from the root mean squared error of calculation was the number selected.

\section{RESULTS}

The descriptive statistics of animal performance, dietary characteristics, $\mathrm{CH}_{4}$ emission, and GC-determined MFA concentrations are presented in Table 2. The GCdetermined MFA-based $\mathrm{CH}_{4}$ production, yield, and intensity prediction models are shown in Table 3. In the final models, considering the odd- and branchedchain fatty acids (OBCFA), $\mathrm{CH}_{4}$ production was positively associated with $\mathrm{C} 15: 0(P=0.002), \mathrm{CH}_{4}$ yield was positively associated with iso $\mathrm{C} 15: 0$ and $\mathrm{C} 17: 0(P$ $<0.003)$ but negatively associated with anteiso C15:0 $(P<0.001)$, and $\mathrm{CH}_{4}$ intensity was positively associated with iso $\mathrm{C} 15: 0$ and iso $\mathrm{C} 17: 0(P<0.001)$. The relation between $\mathrm{CH}_{4}$ emissions and the $\mathrm{C} 18: 1, \mathrm{C} 18: 2$, C18:3 isomers was generally negative $(P<0.010)$, with the exception of the positive association between $\mathrm{CH}_{4}$ production and C18:2n-6 $(P=0.005)$. Additionally, $\mathrm{CH}_{4}$ production was negatively associated with $\mathrm{C} 24: 0$ $(P=0.007)$ and positively associated with $\mathrm{C} 20: 4 \mathrm{n}-3$ $(P=0.002)$, and $\mathrm{CH}_{4}$ intensity was positively associated with $\mathrm{C} 22: 5 n-3(P<0.001)$. The FTIR-based $\mathrm{CH}_{4}$ prediction models were based on the regression between 
the wavenumbers and $\mathrm{CH}_{4}$ production, yield, or intensity, as illustrated in Figure 1. Certain wavenumbers were not related to $\mathrm{CH}_{4}$ emissions (i.e., regression vector close to 0 ), whereas other wavenumbers were clearly positively or negatively related to $\mathrm{CH}_{4}$ emissions. The strength and the direction (positive or negative) of the correlations as well as the correlated wavenumbers differed between the different units of $\mathrm{CH}_{4}$ emission (i.e., production, yield, and intensity; Figure 1).

The evaluation results (i.e., $\mathrm{R}^{2}$, RMSEP, and CCC analysis) of the GC-determined MFA-based and FTIRbased $\mathrm{CH}_{4}$ prediction models are shown in Table 4 . The observed versus predicted $\mathrm{CH}_{4}$ production, yield, and intensity plots of the GC-determined MFA-based and FTIR-based $\mathrm{CH}_{4}$ prediction models are shown in Figures $2 \mathrm{~A}$ and $3 \mathrm{~A}$, respectively. The residual (i.e., observed minus predicted) versus predicted $\mathrm{CH}_{4}$ production, yield, and intensity plots of the GC-determined MFA-based and FTIR-based $\mathrm{CH}_{4}$ prediction models are shown in Figures $2 \mathrm{~B}$ and $3 \mathrm{~B}$, respectively. The $\mathrm{R}^{2}$, RMSEP (\%), and CCC of the GC-determined MFAbased $\mathrm{CH}_{4}$ prediction models ranged from 0.40 to 0.62 , from 7.1 to $10.9 \%$, and from 0.59 to 0.77 , respectively (Table 4). The $\mathrm{R}^{2}$, RMSEP (\%), and CCC of the FTIRbased $\mathrm{CH}_{4}$ prediction models ranged from 0.25 to 0.56 , from 8.2 to $11.8 \%$, and from 0.40 to 0.72 , respectively. Based on the CCC, for both GC-determined MFA and FTIR, the prediction model for $\mathrm{CH}_{4}$ yield had the lowest prediction potential (moderate predicting ability for both MFA- and FTIR-based models), and the prediction model for $\mathrm{CH}_{4}$ intensity had the highest prediction potential (substantial predicting ability for both MFAand FTIR-based models). The MFA- and FTIR-based prediction models for $\mathrm{CH}_{4}$ production had substantial and moderate predicting ability, respectively. The variation in predicted $\mathrm{CH}_{4}$ emission was smaller than that in the observed $\mathrm{CH}_{4}$ emission, in particular for $\mathrm{CH}_{4}$ yield, as indicated by the variable $v$ (scale shift; the relative difference in standard deviation between predicted and observed values). The scale shift was greater for FTIRbased prediction models ( $v$ ranged from 1.33 to 2.00) than for GC-determined MFA-based prediction models ( $v$ ranged from 1.26 to 1.55).

The RPD statistic, that relates the standard error of prediction to the standard deviation of the original reference data, was smaller than 1.58 for the GC-determined MFA-based $\mathrm{CH}_{4}$ prediction models and smaller than 1.39 for the FTIR-based $\mathrm{CH}_{4}$ prediction models (Table 4), suggesting unsatisfactory prediction ability. The Pearson correlations between GC-determined MFA-predicted and FTIR-predicted $\mathrm{CH}_{4}$ production, $\mathrm{CH}_{4}$ yield, and $\mathrm{CH}_{4}$ intensity were $0.62(P<0.001)$, $0.51(P<0.001)$, and $0.69(P<0.001)$, respectively (Figure 4).
The results of the internal cross validation of all GC-determined MFA-based and FTIR-based $\mathrm{CH}_{4}$ prediction models are also shown in Table 4 . The average number of GC-determined MFA included in the GC-determined MFA internal cross validation models varied between 4 and 5 , and the average number of LV in the FTIR internal cross validation models varied between 4 and 6 . The $\mathrm{R}^{2} \mathrm{CV}$ and the RMSECV of the GCdetermined MFA-based $\mathrm{CH}_{4}$ prediction models ranged from 0.38 to 0.63 and from 8.1 to $11.6 \%$, respectively. The $\mathrm{R}^{2} \mathrm{CV}$ and the RMSECV of the FTIR-based $\mathrm{CH}_{4}$ prediction models ranged from 0.19 to 0.49 and from 8.6 to $12.8 \%$, respectively.

\section{DISCUSSION}

This is the first study evaluating and comparing the $\mathrm{CH}_{4}$ prediction potential of GC-determined MFA and milk FTIR spectra for $\mathrm{CH}_{4}$ data obtained in climate respiration chambers. Data were obtained from dairy cattle experiments where type of forage, forage quality, and forage-to-concentrate ratio were varied, without use of $\mathrm{CH}_{4}$ mitigating additives. Our results indicated that GC-determined MFA-based prediction models had a higher prediction potential than did the FTIR-based models and described a larger amount of the observed variation in $\mathrm{CH}_{4}$ emission.

\section{GC-Determined MFA-Based $\mathrm{CH}_{4}$ Prediction Models}

All $\mathrm{CH}_{4}$ prediction models were based on OBCFA and long-chain fatty acids ( $>16$ carbons). No shortand medium-straight, even-chain fatty acids $(\leq 16$ carbons) were included in any of the GC-determined MFA-based $\mathrm{CH}_{4}$ prediction models, despite the fact that these are synthesized de novo in the mammary gland from acetate and BHB produced in the rumen, which are both reported to be positively associated with $\mathrm{CH}_{4}$ emission (Ellis et al., 2008). As reviewed by van Gastelen and Dijkstra (2016), these short- and medium-straight, even-chain fatty acids were usually not included in the GC-determined MFA-based $\mathrm{CH}_{4}$ prediction equations $(n=6)$ previously developed, except for $\mathrm{C} 4: 0$ and $\mathrm{C} 16: 0$, which were included in one equation each. The association found between $\mathrm{CH}_{4}$ emissions and both iso and anteiso OBCFA in the present study is in agreement with iso OBCFA being more abundant in fibrolytic bacteria and anteiso OBCFA being more abundant in amylolytic bacteria (Vlaeminck et al., 2006). Both C15:0 and C17:0 were found to be positively associated with $\mathrm{CH}_{4}$ emissions, which is in disagreement with the findings of Vlaeminck et al. (2006) and Rico et al. (2016) but in agreement with the findings of Chilliard et al. (2009), Dijkstra et 
Table 2. Descriptive statistics of animal performance, dietary characteristics, methane emission, and the milk fatty acid profile determined with GC $(\mathrm{n}=218)$

\begin{tabular}{|c|c|c|c|c|c|}
\hline Variable & Mean & Median & $\mathrm{SD}$ & Minimum & Maximum \\
\hline \multicolumn{6}{|l|}{ Animal performance } \\
\hline BW (kg) & 617 & 617 & 59.7 & 462 & 817 \\
\hline Parity & 2.7 & 3.0 & 1.38 & 1.0 & 7.0 \\
\hline DIM & 179 & 185 & 85.2 & 59 & 567 \\
\hline Milk yield (kg/d) & 24.3 & 23.9 & 5.42 & 11.3 & 36.8 \\
\hline $\operatorname{FPCM}^{1}(\mathrm{~kg} / \mathrm{d})$ & 25.9 & 25.3 & 5.06 & 12.3 & 39.9 \\
\hline Milk fat content (g/100 g milk) & 4.67 & 4.67 & 0.659 & 2.94 & 6.70 \\
\hline Milk CP content (g/100 g milk) & 3.37 & 3.30 & 0.406 & 2.62 & 5.00 \\
\hline Milk anhydrous lactose content (g/100 g milk) & 4.57 & 4.59 & 0.221 & 3.80 & 5.03 \\
\hline DMI $(\mathrm{kg} / \mathrm{d})$ & 16.3 & 16.1 & 2.18 & 10.8 & 24.5 \\
\hline \multicolumn{6}{|c|}{ Dietary characteristics (g/kg of DM, unless stated otherwise) } \\
\hline $\mathrm{DM}(\mathrm{g} / \mathrm{kg})$ & 502 & 502 & 101.5 & 306 & 797 \\
\hline Ash & 77 & 79 & 13.5 & 53 & 103 \\
\hline $\mathrm{CP}$ & 176 & 172 & 40.1 & 82 & 251 \\
\hline NDF & 380 & 372 & 49.9 & 242 & 501 \\
\hline $\mathrm{ADF}$ & 221 & 218 & 25.7 & 183 & 291 \\
\hline ADL & 14 & 14 & 4.2 & 6 & 26 \\
\hline Crude fat & 31 & 33 & 6.7 & 21 & 46 \\
\hline Starch & 118 & 79 & 85.5 & 5 & 326 \\
\hline Sugar & 89 & 70 & 59.0 & 21 & 265 \\
\hline Gross energy (MJ/kg of DM) & 18.6 & 18.6 & 0.41 & 17.6 & 19.3 \\
\hline NDF-to-starch ratio $(\mathrm{g} / \mathrm{g})$ & 8.2 & 4.8 & 15.76 & 1.0 & 86.2 \\
\hline \multicolumn{6}{|l|}{ Methane emission } \\
\hline Production (g/d) & 366 & 365 & 53.9 & 234 & 535 \\
\hline Yield (g/kg of DMI) & 22.5 & 22.6 & 2.10 & 17.2 & 28.0 \\
\hline Intensity $(\mathrm{g} / \mathrm{kg}$ of FPCM) & 14.4 & 14.4 & 2.58 & 8.5 & 24.8 \\
\hline \multicolumn{6}{|c|}{ Milk fatty acids ( $\mathrm{g} / 100 \mathrm{~g}$ of fatty acids) determined with $\mathrm{GC}$} \\
\hline $\mathrm{C} 4: 0$ & 3.5 & 3.5 & 0.35 & 1.8 & 4.4 \\
\hline C6:0 & 2.1 & 2.2 & 0.21 & 1.5 & 2.6 \\
\hline $\mathrm{C} 8: 0$ & 1.1 & 1.1 & 0.17 & 0.6 & 1.6 \\
\hline C10:0 & 2.5 & 2.4 & 0.53 & 1.1 & 4.1 \\
\hline $\mathrm{C} 12: 0$ & 2.8 & 2.8 & 0.69 & 1.3 & 4.9 \\
\hline C14:0 & 10.4 & 10.5 & 1.39 & 6.7 & 14.1 \\
\hline iso $\mathrm{C} 14: 0$ & 0.08 & 0.08 & 0.017 & 0.04 & 0.13 \\
\hline $\mathrm{C} 14: 1$ cis-9 & 0.99 & 0.97 & 0.238 & 0.47 & 1.95 \\
\hline $\mathrm{C} 15: 0$ & 0.97 & 0.97 & 0.168 & 0.53 & 1.56 \\
\hline iso $\mathrm{C} 15: 0$ & 0.23 & 0.23 & 0.041 & 0.13 & 0.37 \\
\hline anteiso $\mathrm{C} 15: 0$ & 0.40 & 0.40 & 0.068 & 0.24 & 0.62 \\
\hline C16:0 & 31.7 & 31.7 & 3.35 & 24.6 & 42.3 \\
\hline iso C16:0 & 0.18 & 0.18 & 0.035 & 0.12 & 0.34 \\
\hline C16:1 trans-9 & 0.21 & 0.21 & 0.037 & 0.13 & 0.35 \\
\hline $\mathrm{C} 16: 1$ cis -9 & 1.9 & 1.8 & 0.38 & 1.0 & 3.0 \\
\hline $\mathrm{C} 17: 0$ & 0.65 & 0.64 & 0.099 & 0.44 & 0.96 \\
\hline iso $\mathrm{C} 17: 0$ & 0.40 & 0.39 & 0.060 & 0.25 & 0.63 \\
\hline anteiso $\mathrm{C} 17: 0$ & 0.42 & 0.41 & 0.056 & 0.32 & 0.61 \\
\hline $\mathrm{C} 17: 1$ cis-9 & 0.31 & 0.30 & 0.087 & 0.15 & 0.69 \\
\hline $\mathrm{C} 18: 0$ & 9.6 & 9.7 & 1.61 & 5.0 & 15.2 \\
\hline $\mathrm{C} 18: 1$ cis $-9^{2}$ & 21.0 & 20.7 & 3.83 & 12.3 & 30.5 \\
\hline $\mathrm{C} 18: 1$ cis-12 & 0.18 & 0.15 & 0.075 & 0.07 & 0.47 \\
\hline $\mathrm{C} 18: 1$ cis-13 & 0.13 & 0.13 & 0.037 & 0.05 & 0.27 \\
\hline $\mathrm{C} 18: 1$ trans -6 & 0.20 & 0.19 & 0.051 & 0.06 & 0.42 \\
\hline C18:1 trans- 9 & 0.15 & 0.14 & 0.026 & 0.08 & 0.25 \\
\hline $\mathrm{C} 18: 1$ trans -10 & 0.19 & 0.16 & 0.091 & 0.00 & 0.65 \\
\hline $\mathrm{C} 18: 1$ trans -11 & 0.89 & 0.88 & 0.221 & 0.17 & 2.18 \\
\hline $\mathrm{C} 18: 1$ trans $-15+\mathrm{C} 18: 1$ cis- 11 & 0.77 & 0.75 & 0.171 & 0.33 & 1.23 \\
\hline $\mathrm{C} 18: 2$ cis -9, trans -11 & 0.42 & 0.40 & 0.116 & 0.20 & 1.29 \\
\hline $\mathrm{C} 18: 2 \mathrm{n}-6$ & 1.5 & 1.5 & 0.24 & 0.9 & 2.4 \\
\hline $\mathrm{C} 18: 3 \mathrm{n}-3$ & 0.47 & 0.48 & 0.154 & 0.14 & 0.98 \\
\hline C18:3n-6 & 0.07 & 0.07 & 0.014 & 0.04 & 0.13 \\
\hline $\mathrm{C} 20: 0$ & 0.13 & 0.13 & 0.019 & 0.08 & 0.19 \\
\hline $\mathrm{C} 20: 1$ cis- 11 & 0.06 & 0.06 & 0.022 & 0.00 & 0.12 \\
\hline $\mathrm{C} 20: 2 \mathrm{n}-6$ & 0.04 & 0.04 & 0.007 & 0.02 & 0.07 \\
\hline $\mathrm{C} 20: 3 \mathrm{n}-6$ & 0.07 & 0.07 & 0.019 & 0.03 & 0.13 \\
\hline $\mathrm{C} 20: 4 \mathrm{n}-3$ & 0.03 & 0.03 & 0.026 & 0.00 & 0.13 \\
\hline $\mathrm{C} 20: 4 n-6$ & 0.11 & 0.11 & 0.024 & 0.05 & 0.18 \\
\hline $\mathrm{C} 20: 5 \mathrm{n}-3$ & 0.06 & 0.06 & 0.013 & 0.03 & 0.09 \\
\hline $\mathrm{C} 22: 0$ & 0.06 & 0.06 & 0.014 & 0.00 & 0.11 \\
\hline $\mathrm{C} 22: 5 \mathrm{n}-3$ & 0.08 & 0.08 & 0.019 & 0.04 & 0.14 \\
\hline $\mathrm{C} 24: 0$ & 0.04 & 0.04 & 0.013 & 0.00 & 0.08 \\
\hline
\end{tabular}

${ }^{1}$ Fat- and protein-corrected milk $(\mathrm{FPCM} ; \mathrm{kg} / \mathrm{d})=[0.337+0.116 \times$ fat $(\mathrm{g} / 100 \mathrm{~g}$ of milk $)+0.06 \times$ protein $(\mathrm{g} / 100 \mathrm{~g}$ of milk $)] \times$ milk yield $(\mathrm{kg} / \mathrm{d})(\mathrm{CVB}, 2012)$. ${ }^{3} \mathrm{C} 18: 1$ cis-9 represents the sum of C18:1 cis-9 and C18:1 trans-12; these 2 fatty acids could not be separated in the analysis. The portion of C18:1 trans-12 is considered to be negligible because this fatty acid is always present in small amounts. 
al. (2011) and van Lingen et al. (2014). The negative relations between $\mathrm{C} 18: 1, \mathrm{C} 18: 2$, and $\mathrm{C} 18: 3$ isomers in milk and $\mathrm{CH}_{4}$ emission are in agreement with several other studies (e.g., van Lingen et al., 2014 and Rico et al., 2016). The associations between $\mathrm{CH}_{4}$ emissions and long-chain fatty acids have been reported before (i.e., Chilliard et al., 2009; Rico et al., 2016; van Gastelen et al., 2017a), suggesting that these GC-determined MFA are important in terms of $\mathrm{CH}_{4}$ prediction.

In general, the prediction potential of the GC-determined MFA-based $\mathrm{CH}_{4}$ prediction models appeared to be moderate to substantial, with the $\mathrm{CCC}$ ranging from 0.40 to 0.77 . The observed $\mathrm{R}^{2}$ values ranged from 0.40 to 0.62 and were lower than the ones reported by Dijkstra et al. (2011) for $\mathrm{CH}_{4}$ yield and by Chilliard et al. (2009), Mohammed et al. (2011), and Rico et al. (2016) for $\mathrm{CH}_{4}$ production, but the observed $\mathrm{R}^{2}$ values were of similar magnitude to those of van Lingen et al. (2014) and van Gastelen et al. (2017a). Recent research, including the present study, on the relationship between GC-determined MFA and $\mathrm{CH}_{4}$ emission gives inconsistent results. Although some studies found a clear and strong relation between GC-determined MFA and $\mathrm{CH}_{4}$ emission (e.g., Chilliard et al., 2009; Dijkstra et al., 2011), other studies concluded that GC-determined MFA alone might not be suitable to develop universal $\mathrm{CH}_{4}$ prediction models (e.g., Mohammed et al., 2011), and more recently, Castro-Montoya et al. (2017) concluded that GC-determined MFA are not reliable predictors for specific amounts of $\mathrm{CH}_{4}$ emitted by a cow based on the coefficient of determination of validation ranging from 0.18 to 0.41 . Even the studies that do find a clear relation between GC-determined MFA and $\mathrm{CH}_{4}$ emissions do not describe similar prediction models using the same GC-determined MFA. The discrepancies between these studies have been reviewed by van Gastelen and Dijkstra (2016). Many factors can influence GC-determined MFA concentrations and, therefore, the relation between GC-determined MFA and $\mathrm{CH}_{4}$ emissions (Gengler et al., 2016), such as dietary composition (e.g., Mohammed et al., 2011; Dijkstra et al., 2016) and lactation stage (Vanrobays et al., 2016). Moreover, it should be noted that previous analyses were often based on data of cattle fed lipid supplements or feed additives, whereas in the present study dietary contrasts included variation in forage-to-concentrate ratio, type of forage, and forage quality only.

The difference between $\mathrm{R}^{2}$ and $\mathrm{R}^{2} \mathrm{CV}$ for the GCdetermined MFA-based $\mathrm{CH}_{4}$ prediction models was small (0.07 for $\mathrm{CH}_{4}$ production, 0.02 for $\mathrm{CH}_{4}$ yield, and 0.01 for $\mathrm{CH}_{4}$ intensity; Table 4). These small differences indicate that all GC-determined MFA-based $\mathrm{CH}_{4}$ prediction models are robust in terms of $\mathrm{CH}_{4}$ prediction. The GC-determined MFA-based $\mathrm{CH}_{4}$ prediction models were also assessed for robustness in terms of composition of the prediction models. All 4 GC-determined MFA that were part of the overall prediction model for $\mathrm{CH}_{4}$ intensity (Table 3 ) were also selected in the prediction models developed in the 10-fold cross validation (results not shown). Three of the four GCdetermined MFA were included in all 10 models (i.e., iso $\mathrm{C} 15: 0$, iso $\mathrm{C} 17: 0$, and $\mathrm{C} 18: 1$ trans- $15+\mathrm{C} 18: 1$ cis-

Table 3. The prediction models developed for methane production $(\mathrm{g} / \mathrm{d})$, yield $(\mathrm{g} / \mathrm{kg}$ of DMI), and intensity $\left(\mathrm{g} / \mathrm{kg}\right.$ of $\left.\mathrm{FPCM}^{1}\right)$ based on milk fatty acids determined with GC

\begin{tabular}{llrrr}
\hline Methane emission & Milk fatty acid & Estimate & SE & $P$-value \\
\hline Methane production $(\mathrm{g} / \mathrm{d})$ & Intercept & 507.9 & 28.66 & $<0.001$ \\
& C15:0 & 62.9 & 17.22 & 0.002 \\
& C17:1 cis-9 & -240.6 & 32.29 & 0.007 \\
& C18:1 trans-10 & -202.8 & 47.75 & 0.010 \\
& C18:1 trans-11 & -59.3 & 12.70 & $<0.001$ \\
& C18:2n-6 & 48.1 & 14.08 & 0.005 \\
& C18:3n-3 & -187.1 & 24.40 & $<0.001$ \\
& C20:4n-3 & 326.4 & 104.30 & 0.002 \\
& C24:0 & -816.8 & 230.89 & 0.007 \\
Methane yield $(\mathrm{g} / \mathrm{kg}$ of DMI) & Intercept & 22.9 & 1.27 & $<0.001$ \\
& iso C15:0 & 20.9 & 4.17 & 0.003 \\
& anteiso C15:0 & -9.6 & 2.34 & $<0.001$ \\
& C17:0 & 7.6 & 1.26 & $<0.001$ \\
& C18:1 trans-11 & -2.4 & 0.52 & $<0.001$ \\
& C18:1 trans-15 + C18:1 cis-11 & -2.7 & 0.84 & $<0.001$ \\
& C18:3n-3 & -4.4 & 0.81 & $<0.001$ \\
Methane intensity $(\mathrm{g} / \mathrm{kg}$ of $\mathrm{FPCM})$ & Intercept & 8.0 & 1.13 & $<0.001$ \\
& iso C15:0 & 24.8 & 3.66 & $<0.001$ \\
& iso C17:0 & 10.3 & 2.30 & $<0.001$ \\
& C18:1 trans-15 $+\mathrm{C} 18: 1$ cis-11 & -6.6 & 0.95 & $<0.001$ \\
& C22:5n-3 & 22.7 & 6.61 & $<0.001$ \\
\hline
\end{tabular}

${ }^{1}$ Fat- and protein-corrected milk $(\mathrm{FPCM} ; \mathrm{kg} / \mathrm{d})=[0.337+0.116 \times$ fat $(\mathrm{g} / 100 \mathrm{~g}$ of milk $)+0.06 \times$ protein $(\mathrm{g} / 100 \mathrm{~g}$ of milk $)] \times$ milk yield $(\mathrm{kg} / \mathrm{d})(\mathrm{CVB}, 2012)$. 
A
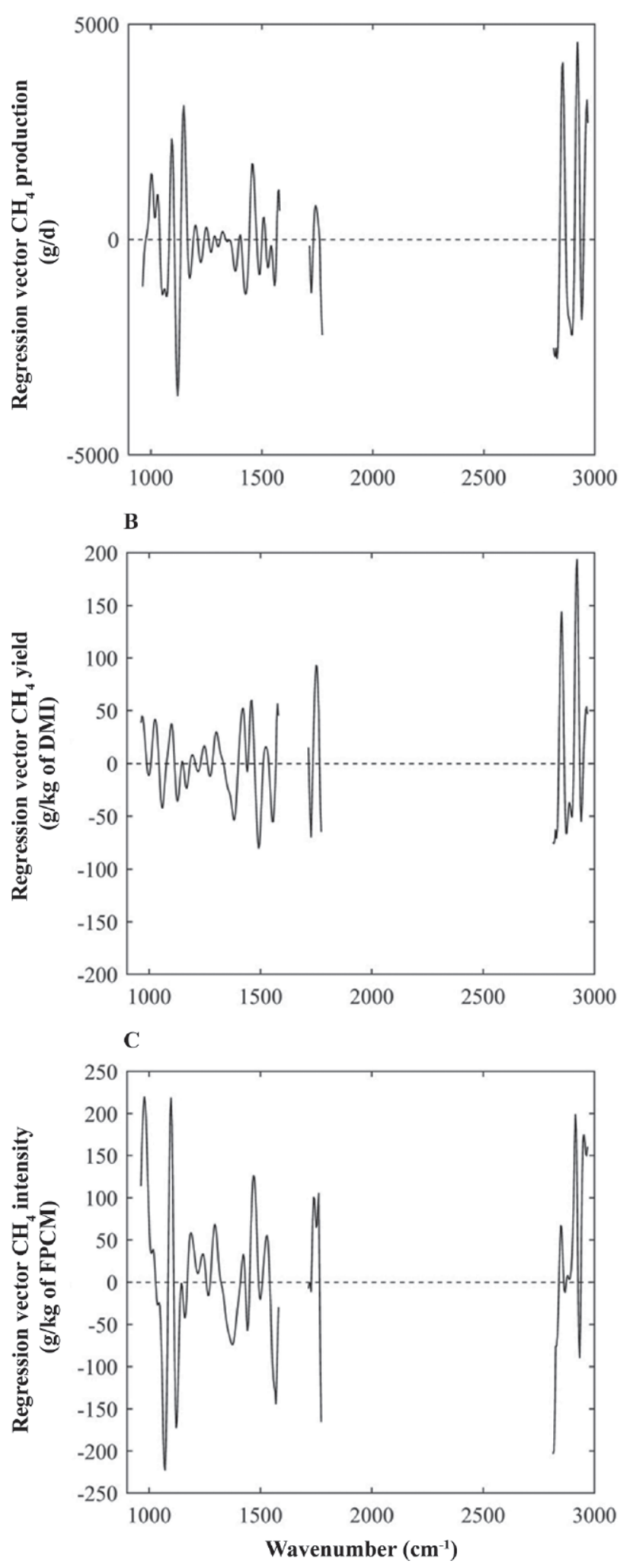

Figure 1. The regression vectors of the partial least squares models for methane (A) production (g/d), (B) yield (g/kg of DMI), and (C) intensity $[\mathrm{g} / \mathrm{kg}$ of fat- and protein-corrected milk (FPCM)] plotted against wavenumbers $\left(\mathrm{cm}^{-1}\right)$.
11), which shows the robustness of the GC-determined MFA-based prediction model for $\mathrm{CH}_{4}$ intensity in terms of composition. In comparison, all 6 GC-determined MFA of the MFA-based prediction model for $\mathrm{CH}_{4}$ yield were selected in the 10-fold cross validation. Although only 1 GC-determined MFA of the GC-determined MFA-based model (i.e., C18:3n-3) was included in all 10 models of the cross validation, the other 5 GC-determined MFA were included in 6 to 8 of the 10 models. However, of the 8 GC-determined MFA in the MFAbased prediction model for $\mathrm{CH}_{4}$ production, only 5 were also selected in the 10-fold cross validation, of which 1 GC-determined MFA (i.e., C18:3n-3) was included in all 10 models. Moreover, 3 of the GC-determined MFA in the GC-determined MFA-based $\mathrm{CH}_{4}$ production prediction model were not selected in any of the 10 models of the cross validation (i.e., C18:1 trans-10, C18:2n-6, and C20:4n-3). This illustrates that the GC-determined MFA-based prediction model for $\mathrm{CH}_{4}$ production in particular is less robust in comparison with the GC-determined MFA-based prediction model for $\mathrm{CH}_{4}$ intensity and $\mathrm{CH}_{4}$ yield.

\section{FTIR-Based $\mathrm{CH}_{4}$ Prediction Models}

In general, the prediction potential of the FTIRbased $\mathrm{CH}_{4}$ prediction models appeared to be moderate to substantial, with the CCC ranging from 0.40 to 0.72 and the $\mathrm{R}^{2}$ ranging from 0.25 to 0.56 . From the regression vector (Figure 1), it appears that bands around $975 \mathrm{~cm}^{-1}, 1,075$ to $1,150 \mathrm{~cm}^{-1}, 1,450 \mathrm{~cm}^{-1}, 1,500$ to $1,575 \mathrm{~cm}^{-1}, 1,750 \mathrm{~cm}^{-1}$, and 2,850 to $3,000 \mathrm{~cm}^{-1}$ are important for the prediction of $\mathrm{CH}_{4}$ emissions. The latter region and the bands around $1,175 \mathrm{~cm}^{-1}$ and $1,750 \mathrm{~cm}^{-1}$ are commonly used to quantify milk fat content (Safar et al., 1994; Dupuy et al., 1996; Yang and Irudayaraj, 2000). Protein is expected to have absorption peaks around wavenumbers 1,500 to $1,700 \mathrm{~cm}^{-1}$ (Osborne and Fearn, 1986; McQueen et al., 1995; Dufour et al., 1998), with the bands around 1,500 to $1,575 \mathrm{~cm}^{-1}$ coinciding with the amide II band (Etzion et al., 2004). Additionally, the infrared region between 1,000 and $1,100 \mathrm{~cm}^{-1}$ provides information on sugar molecules (Hashimoto and Kameoka, 2008). This suggests that the bands of the FTIR spectra that are important to determine the milk composition, such as fat and protein content, are also important for the prediction of $\mathrm{CH}_{4}$ emission. However, as illustrated by Negussie et al. (2017), milk fat and milk protein content have low $\mathrm{CH}_{4}$ prediction potential. This is also observed in the present study, in which milk protein and milk fat contents were relatively weakly associated with $\mathrm{CH}_{4}$ emissions measured in the climate respiration chambers, except for $\mathrm{CH}_{4}$ intensity, for which the calculation includes milk fat and 
VAN GASTELEN ET AL.

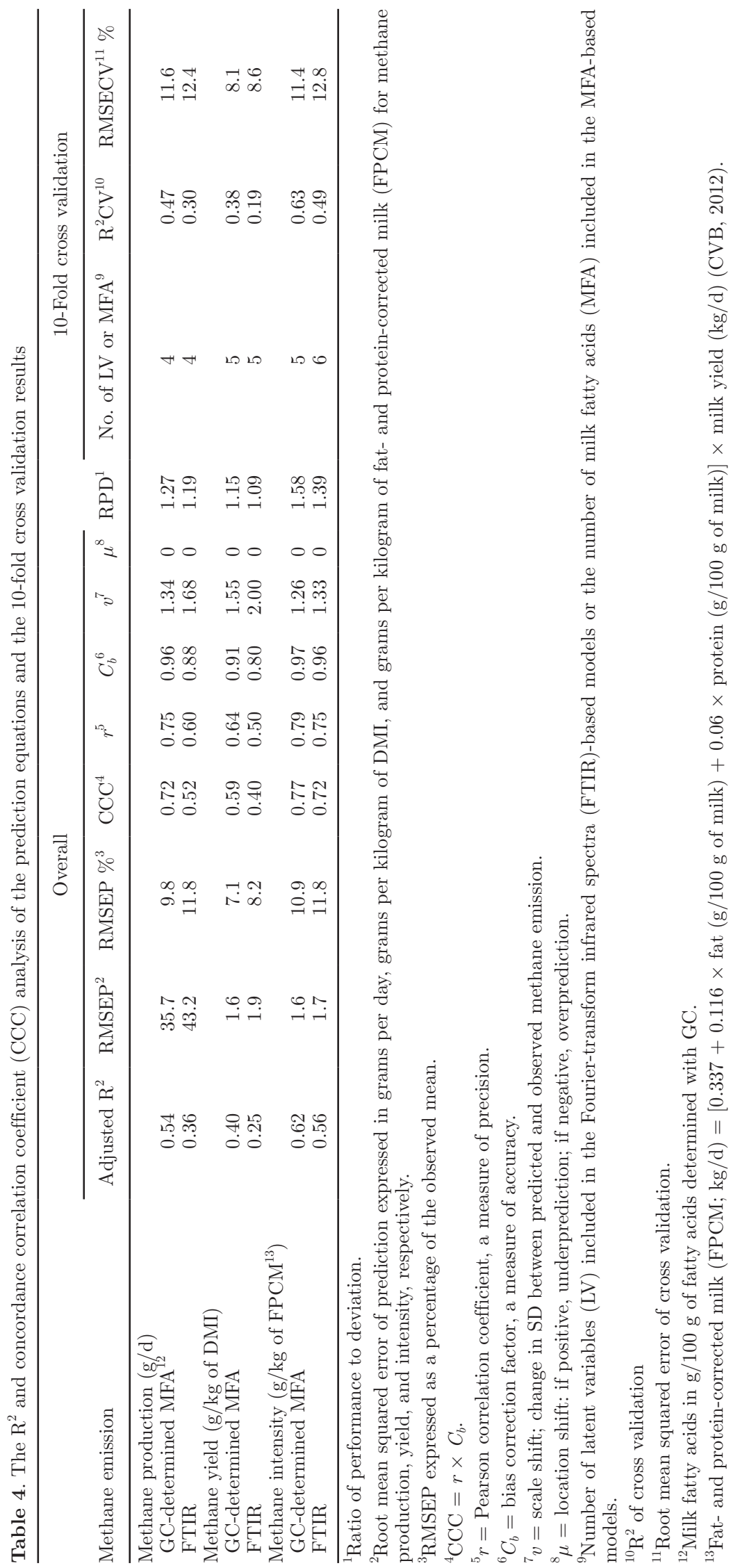




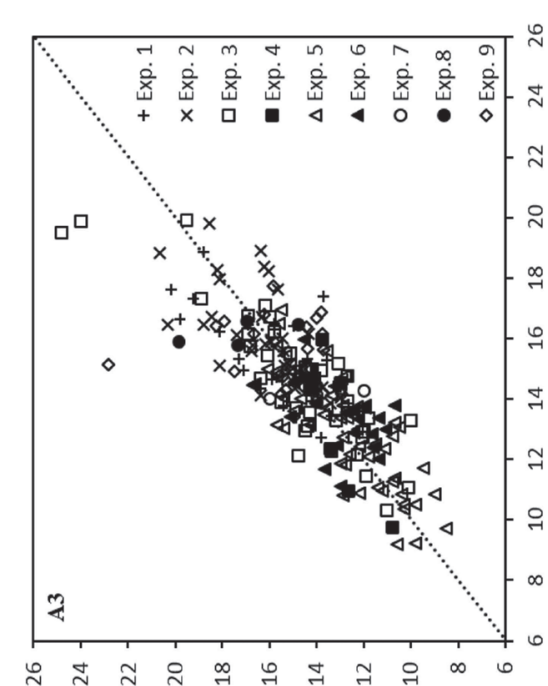

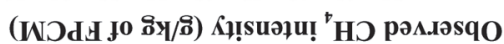

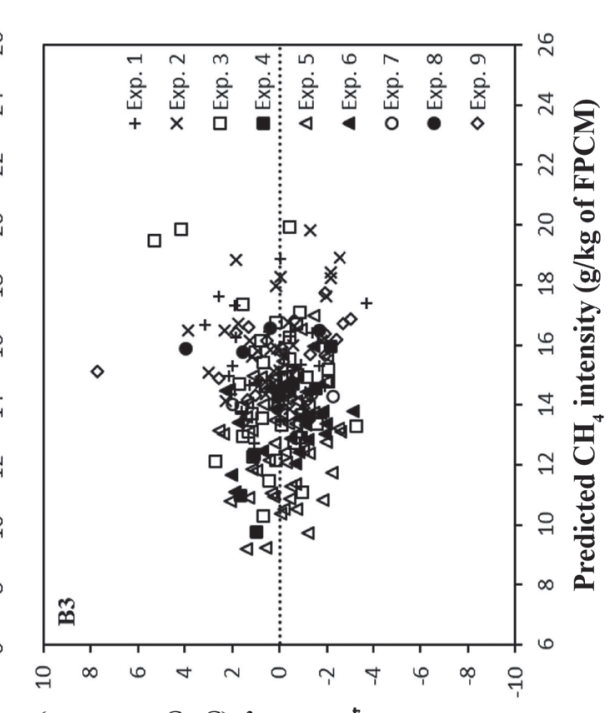

密量

寻

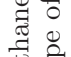

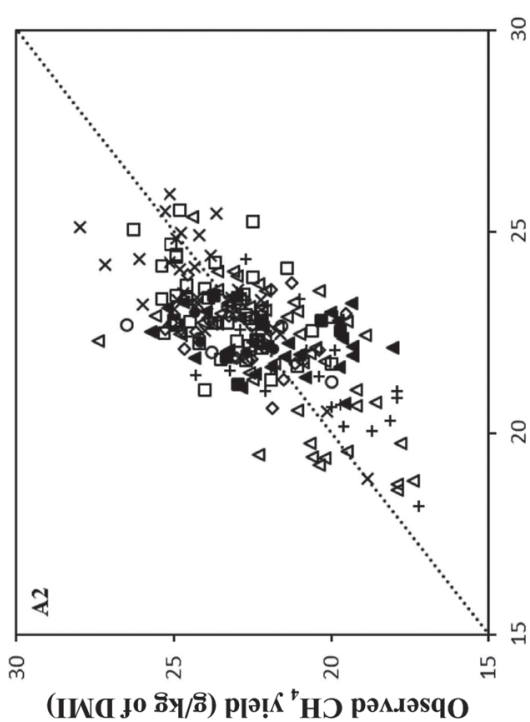

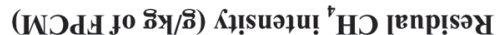

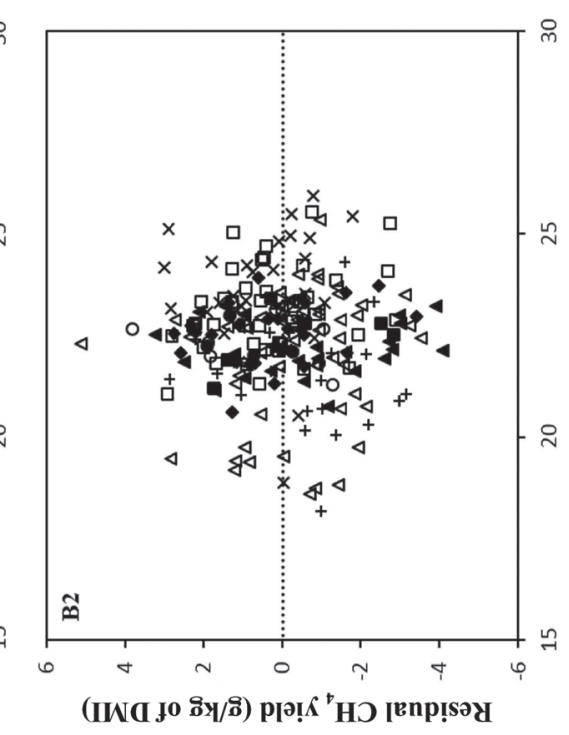

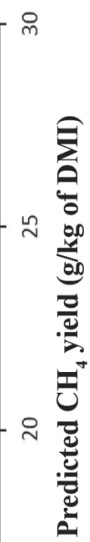

مอ

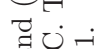

要

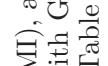

西空

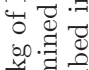

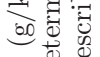

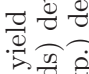

总通

要要

$\widehat{\theta}^{60} \cdot$

sic

表:

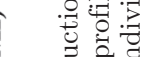

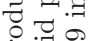

:

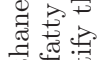

语

.

$\exists \approx \frac{\pi}{0}$

षै $\bar{\delta}$ है

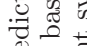

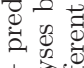

栗

ब.

足量

S.

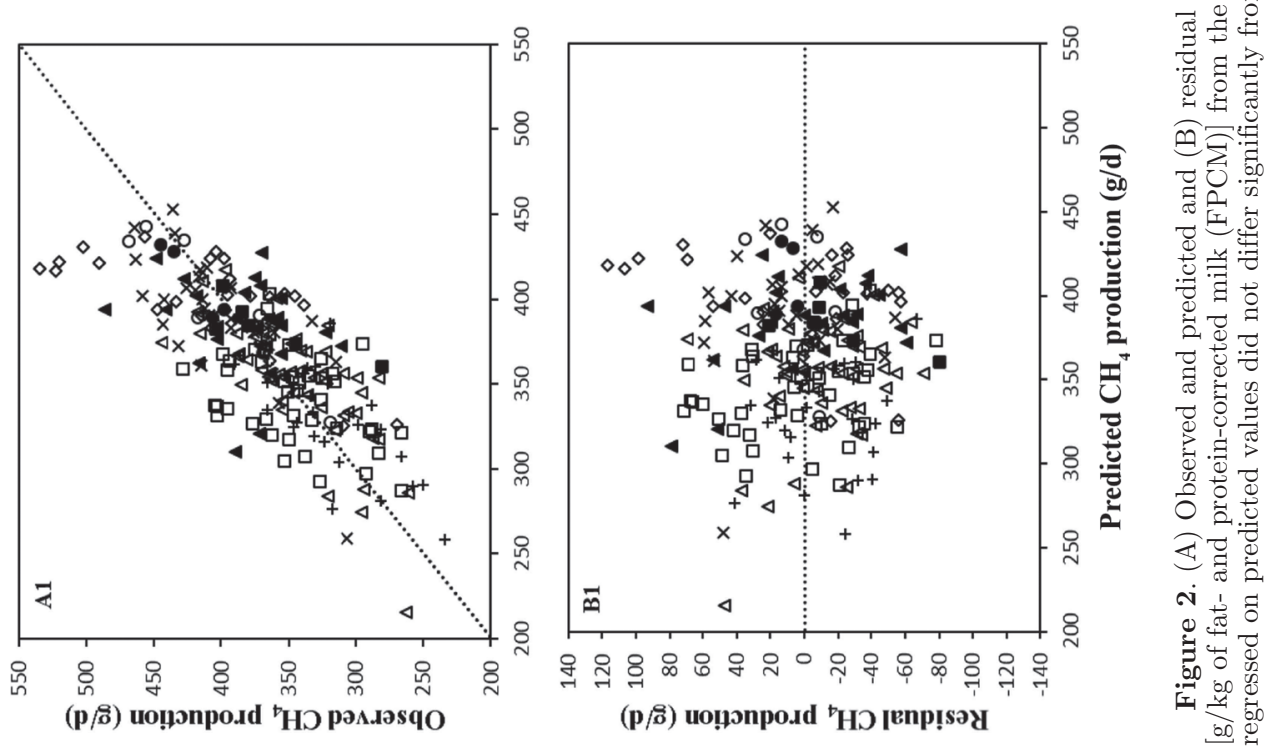



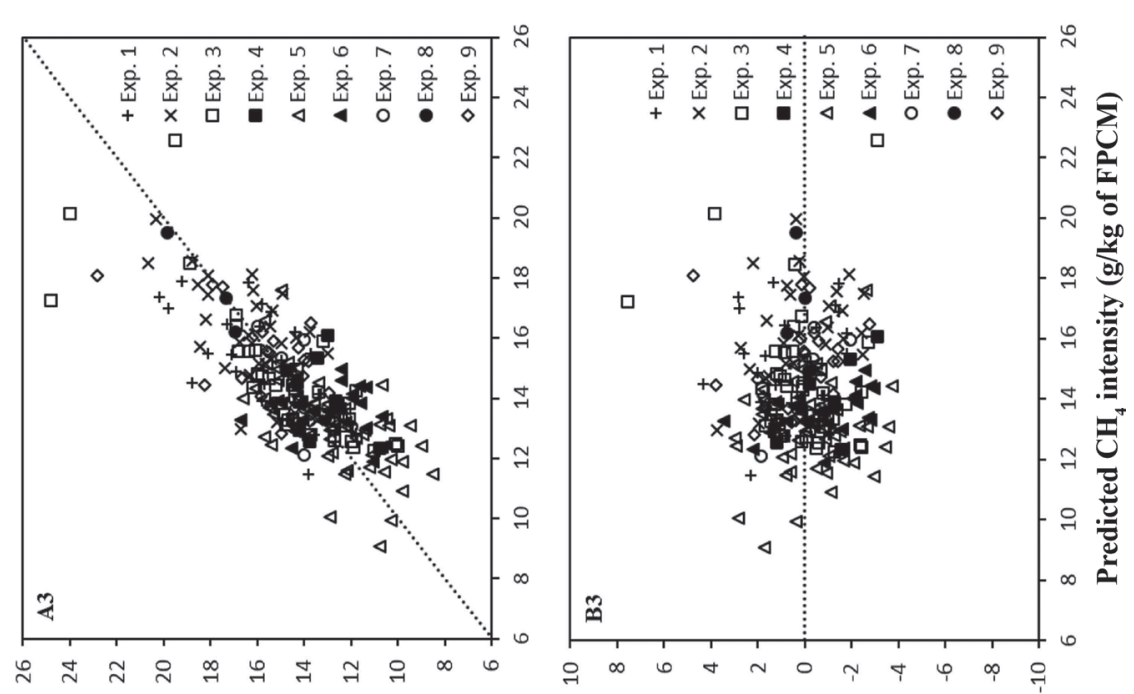

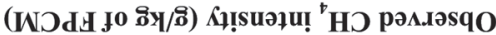

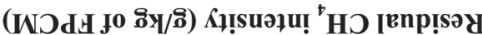
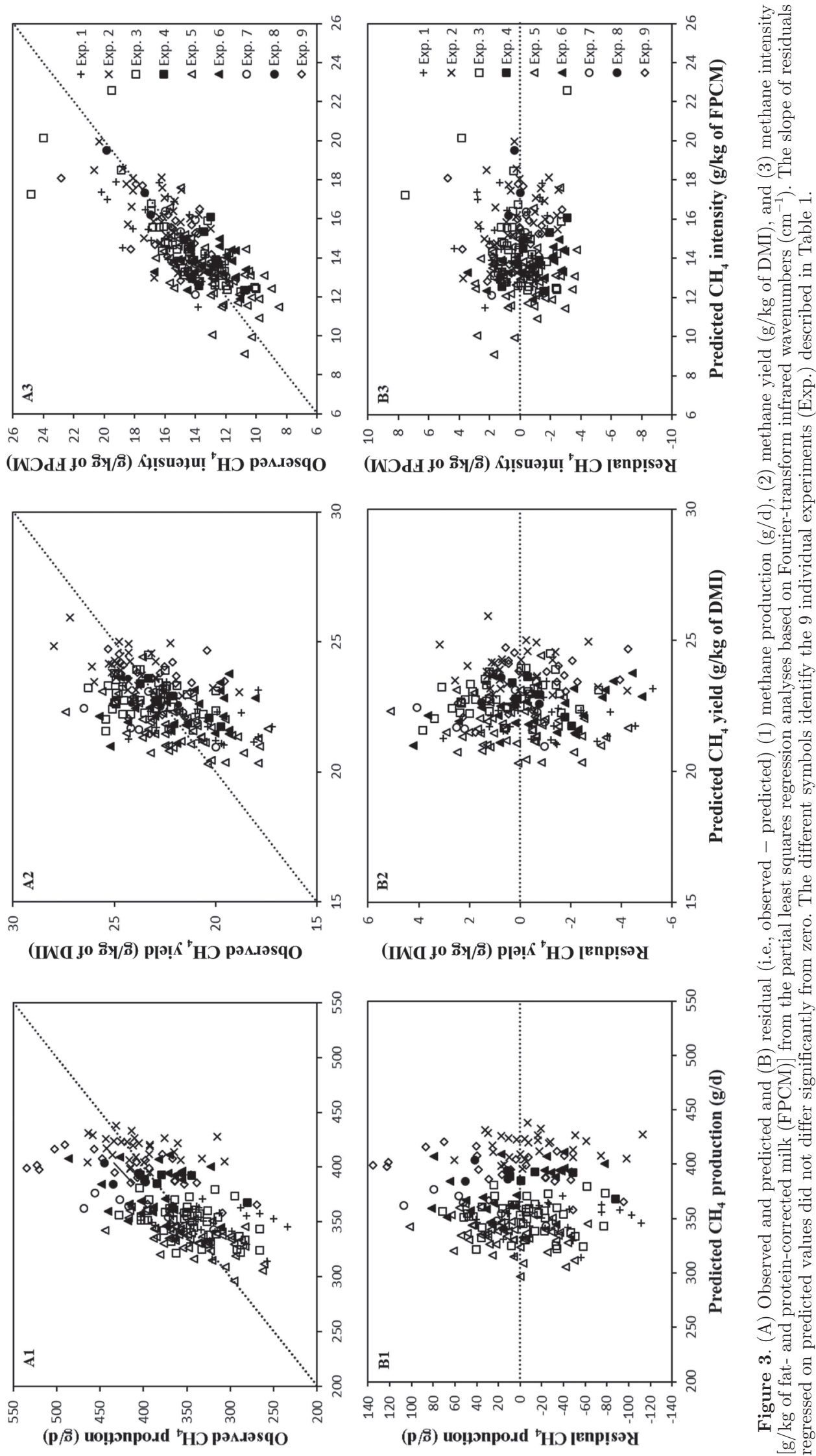

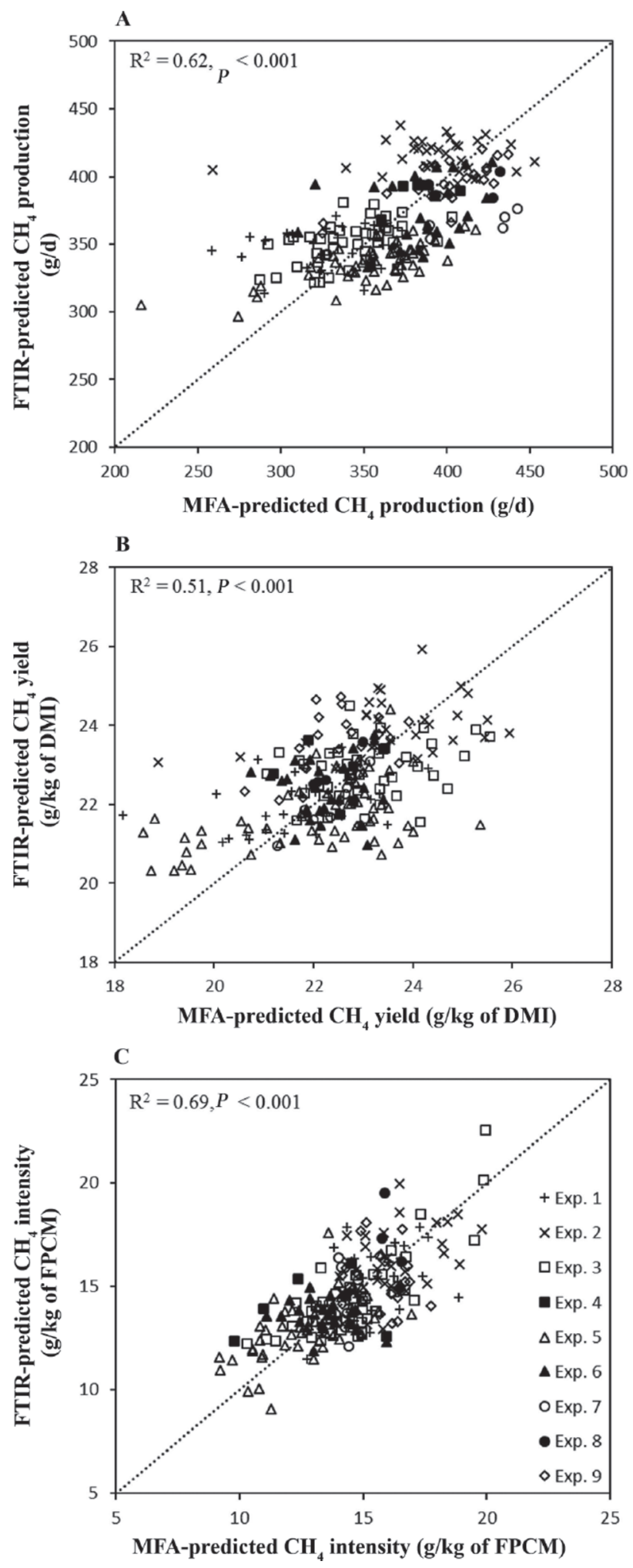

Figure 4. The relationship between methane production $(\mathrm{g} / \mathrm{d})$, yield $(\mathrm{g} / \mathrm{kg}$ of DMI), and intensity $[\mathrm{g} / \mathrm{kg}$ of fat- and protein-corrected milk (FPCM)] predicted with milk fatty acid (MFA) profiles determined with GC and predicted with milk Fourier-transform infrared spectra (FTIR). The different symbols identify the 9 individual experiments (Exp.) described in Table 1. protein contents. Methane yield was correlated with fat content $(r=0.17, P=0.010)$ and tended to be related to protein content $(r=0.12, P=0.066)$, whereas no significant correlations were observed for $\mathrm{CH}_{4}$ production. However, as expected from the similarity in FTIR spectra bands, FTIR-predicted $\mathrm{CH}_{4}$ emissions were more strongly related to milk protein content $(r=0.11$, $P=0.096$ for $\mathrm{CH}_{4}$ production; $r=0.32, P<0.001$ for $\mathrm{CH}_{4}$ yield; $r=0.64, P<0.001$ for $\mathrm{CH}_{4}$ intensity) and to milk fat content $\left(r=-0.11, P=0.094\right.$ for $\mathrm{CH}_{4}$ production; $r=0.37, P<0.001$ for $\mathrm{CH}_{4}$ yield; $r=0.13$, $P=0.053$ for $\mathrm{CH}_{4}$ intensity).

The differences between $\mathrm{R}^{2}$ and $\mathrm{R}^{2} \mathrm{CV}$ for the milk FTIR-based $\mathrm{CH}_{4}$ prediction models were 0.06 for $\mathrm{CH}_{4}$ production, 0.06 for $\mathrm{CH}_{4}$ yield, and 0.07 for $\mathrm{CH}_{4}$ intensity (Table 4). For $\mathrm{CH}_{4}$ yield and intensity, these differences between $\mathrm{R}^{2}$ and $\mathrm{R}^{2} \mathrm{CV}$ of FTIR-based models are somewhat larger than for GC-determined MFA-based models, indicating that GC-determined MFA-based models are slightly more robust. The number of studies on FTIR-based $\mathrm{CH}_{4}$ prediction models is limited. Dehareng et al. (2012) reported FTIR-based prediction models for $\mathrm{CH}_{4}$ production and $\mathrm{CH}_{4}$ intensity $(\mathrm{g} / \mathrm{kg}$ of milk) using the $\mathrm{SF}_{6}$-tracer technique, involving 11 lactating dairy cows and 3 dietary treatments. The prediction potentials of the FTIR-based prediction models reported by Dehareng et al. (2012) were higher than the ones reported in the present study, with the $\mathrm{R}^{2}$ ranging from 0.77 to 0.93 and the $\mathrm{R}^{2} \mathrm{CV}$ ranging from 0.68 to 0.79. Additionally, Vanlierde et al. (2015) developed lactation stage-independent (i.e., including only FTIR spectra) and lactation stage-dependent (i.e., including FTIR spectra and DIM) $\mathrm{CH}_{4}$ prediction models using the $\mathrm{SF}_{6}$-tracer technique, involving 142 lactating dairy cows fed a wide range of diets. Vanlierde et al. (2015) reported, for the lactation stage-independent $\mathrm{CH}_{4}$ prediction model (i.e., comparable to present study), a strong correlation $\left(\mathrm{R}^{2}=0.77\right)$ between observed and predicted $\mathrm{CH}_{4}$ production, which is also higher than that in the present study. However, the previous studies developed FTIR-based $\mathrm{CH}_{4}$ prediction models using multiple measurements of the same cows in a shorter time frame than in our study. Consequently, cows were in a rather similar lactation stage and parity and received the same dietary treatment. The study by Dehareng et al. (2012) involved 11 dairy cows, whereas the prediction models were developed using 77 observations (i.e., 7.00 observations per individual), and the study by Vanlierde et al. (2015) involved 142 dairy cows, whereas the prediction models were developed using 446 observations (i.e., 3.14 observations per individual). This could have positively influenced the performance parameters of their $\mathrm{CH}_{4}$ prediction models; repeated measures are generally more closely related than independent obser- 
vations. Contrary, the present study involved multiple distinct measurements of a limited number of cows (i.e., out of 189 individual dairy cows, 29 cows had 2 observations; 1.15 observations per individual). These observations on the same individual are considered as separate measurements because they were obtained at a different parity and lactation stage as well as a different dietary treatment. Furthermore, the large range of $\mathrm{CH}_{4}$ emissions measured using the $\mathrm{SF}_{6}$-tracer technique might have contributed to the high prediction potentials found in both studies. In the study by Dehareng et al. (2012), $\mathrm{CH}_{4}$ production ranged from 218 to 653 $\mathrm{g} / \mathrm{d}$ and $\mathrm{CH}_{4}$ intensity ranged from 10.2 to $47.1 \mathrm{~g} / \mathrm{kg}$ of milk, and in the study by Vanlierde et al. (2015), $\mathrm{CH}_{4}$ production ranged from approximately 180 to $950 \mathrm{~g} / \mathrm{d}$, which is not within the range of $\mathrm{CH}_{4}$ measurements reported in literature (Appuhamy et al., 2016).

More recently, Shetty et al. (2017) concluded that it is not feasible to predict $\mathrm{CH}_{4}$ emission based on FTIR spectra alone, because of the low prediction accuracies found when models were obtained using FTIR spectra and because of the marginal added value of FTIR spectra in combination with traits such as milk yield and lactation stage. Hence, considerable discrepancy exists between the results obtained in the present study and the 3 aforementioned studies. This discrepancy might be the results of different $\mathrm{CH}_{4}$ emission measurement techniques (i.e., climate respiration chambers, $\mathrm{SF}_{6}$-tracer technique, and the sniffer technique), the size as well as the structure of the population [i.e., ranging from 11 dairy cows in the study by Dehareng et al. (2012) to 490 dairy cows in the study by Shetty et al. (2017)], the prediction and validation methods (i.e., internal cross validation and external validation), and the duration of measurement and the time between $\mathrm{CH}_{4}$ measurements and milk FTIR sampling (Shetty et al., 2017).

\section{Comparison of GC-Determined MFA-Based and FTIR-Based $\mathrm{CH}_{4}$ Prediction Models}

For all $\mathrm{CH}_{4}$ emission units, but particularly for $\mathrm{CH}_{4}$ production and $\mathrm{CH}_{4}$ yield, GC-determined MFA-based prediction models had a higher prediction potential than did the FTIR-based models. This is evident by the lower RMSEP values and higher $\mathrm{R}^{2}$ and $\mathrm{CCC}$ values. The higher CCC values are caused by the higher accuracy $\left(C_{b}\right)$ and, in particular, higher precision $(r)$ of the GC-determined MFA-based $\mathrm{CH}_{4}$ prediction models (Table 4). The relatively larger differences between the GC-determined MFA-based and FTIR-based prediction models for $\mathrm{CH}_{4}$ production and $\mathrm{CH}_{4}$ yield might be explained by GC-determined MFA being more closely linked to the ruminal $\mathrm{CH}_{4}$ production pathways than FTIR spectra. It is known that GC-determined MFA are related to $\mathrm{CH}_{4}$ production because of the common biochemical pathway between $\mathrm{CH}_{4}$ and fatty acids in the rumen (Ellis et al., 2008; Chilliard et al., 2009). As discussed above, the FTIR spectra represent the absorbed light by vibrations at several wavelengths of many milk components, including some GC-determined MFA, urea, citrate, free fatty acids, and fat, protein, and lactose content. The latter 3 solid major milk components have a low $\mathrm{CH}_{4}$ prediction potential (Negussie et al., 2017) and do not seem to be directly linked with ruminal $\mathrm{CH}_{4}$ pathways. The relatively small difference between the GC-determined MFA-based and FTIR-based prediction models for $\mathrm{CH}_{4}$ intensity might be explained by the fact that $\mathrm{CH}_{4}$ intensity takes milk yield into account, which is directly associated with enteric $\mathrm{CH}_{4}$ production by cows and reflected by both the FTIR spectral data and the GC-determined MFA profile, due to dilution effects (Dehareng et al., 2012). This is also illustrated by the somewhat stronger correlation between GC-determined MFA-predicted $\mathrm{CH}_{4}$ intensity and FTIR-predicted $\mathrm{CH}_{4}$ intensity $(\mathrm{r}=0.69)$ compared with the correlation between both methods for $\mathrm{CH}_{4}$ production $(\mathrm{r}=0.62)$ and $\mathrm{CH}_{4}$ yield $(\mathrm{r}=0.51)$.

All $\mathrm{CH}_{4}$ prediction models, GC-determined MFAbased and FTIR-based models, had a scale shift that was different from one $(v>1.26)$. This indicates that a change in standard deviation exists between predicted and observed $\mathrm{CH}_{4}$ values for all $\mathrm{CH}_{4}$ prediction models, which is also visualized in Figures 2 and 3 for GC-determined MFA-based and FTIR-based models, respectively. The variation in predicted $\mathrm{CH}_{4}$ values was clearly smaller than that in observed $\mathrm{CH}_{4}$ values for all $\mathrm{CH}_{4}$ prediction models. However, the scale shift was greater for all the FTIR-based $\mathrm{CH}_{4}$ prediction models ( $v$ ranged from 1.33 to 2.00) than for the GC-determined MFA-based $\mathrm{CH}_{4}$ prediction models ( $v$ ranged from 1.26 to 1.55), which indicates that GC-determined MFA-based $\mathrm{CH}_{4}$ prediction models have the ability to describe more of the observed variation in $\mathrm{CH}_{4}$ emissions compared with FTIR-based prediction models.

The RPD values from the present study are lower than the RPD values reported by Dehareng et al. (2012). The low RPD values from the present study (i.e., $<1.58$ for the GC-determined MFA-based $\mathrm{CH}_{4}$ prediction models and $<1.39$ for the FTIR-based $\mathrm{CH}_{4}$ prediction models) suggest that the prediction ability of these models can be regarded as poor (Williams, 2014). According to Williams and Sobering (1993), a RPD value of 2.5 and above would suggest that the model is satisfactory for screening. A narrow range in the variability of the observations is known to negatively affect predictability of methods of interest (Manley, 2014). Indeed, the coefficient of variation (SD relative to mean) is highest for $\mathrm{CH}_{4}$ intensity (17.9\%), and the models for 
$\mathrm{CH}_{4}$ intensity had relatively the best RPD. The lowest coefficient of variation is for $\mathrm{CH}_{4}$ yield $(9.3 \%)$, and the models for $\mathrm{CH}_{4}$ yield had the smallest RPD values. Moreover, although the respiration chamber method is generally considered to be the golden standard for $\mathrm{CH}_{4}$ measurements (Hammond et al., 2016), its reproducibility as compared with many chemical analyses, for which the RPD statistic was originally developed, is much lower, hence reducing prediction accuracy of the prediction methods. The RPD values would suggest that the $\mathrm{CH}_{4}$ prediction models presented in the current study, GC-determined MFA-based and FTIRbased models, would not be able to classify dairy cows from populations with low variation in $\mathrm{CH}_{4}$ emission into low and high $\mathrm{CH}_{4}$ producers. More variation in the dairy population under evaluation, such as greater variation in animal genetics, in dietary composition, and in production management, could potentially improve the ability of the models to predict $\mathrm{CH}_{4}$ emission (Dehareng et al., 2012).

The present study did not take lactation stage into account. Although lactation stage is a poor $\mathrm{CH}_{4}$ proxy when considered alone (Negussie et al., 2017), Vanlierde et al. (2015) demonstrated that lactation stage in combination with FTIR improved the $\mathrm{CH}_{4}$ prediction model. Vanlierde et al. (2015) developed both lactation stage-independent and lactation stage-dependent $\mathrm{CH}_{4}$ prediction models. The average $\mathrm{CH}_{4}$ production (g/d) predicted by both models was similar $(416 \pm 63$ $\mathrm{g} / \mathrm{d}$, mean $\pm \mathrm{SD}$ ). However, in contrast to the lactation stage-independent prediction model, the lactation stage-dependent prediction model showed biologically meaningful behavior throughout lactation: an increase in $\mathrm{CH}_{4}$ production $(\mathrm{g} / \mathrm{d})$ after calving up to approximately 100 DIM, followed by a gradual decline toward the end of lactation (Vanlierde et al., 2015). This effect of lactation stage could also be important for the MFA-based $\mathrm{CH}_{4}$ prediction models, because Vanrobays et al. (2016) clearly demonstrated that the correlations between GC-determined MFA and $\mathrm{CH}_{4}$ production in dairy cows vary according to lactation stage. We therefore acknowledge that the $\mathrm{CH}_{4}$ prediction models of the present study may be improved in terms of predictive power and robustness, when combining GC-determined MFA or FTIR with lactation stage. We were, however, not able to confirm this, because differences in lactation stage were confounded by differences in dietary composition in the data set used in the present study. Additionally, it should be noted that this study was based on 9 experiments with forage-based diets only (forage varied between 700 and $850 \mathrm{~g} / \mathrm{kg}$ of $\mathrm{DM}$ ). Furthermore, the milk production of the cows did not exceed $36.8 \mathrm{~kg} / \mathrm{d}$, and all cows were restricted in their feed intake to avoid confounding effects of DMI on $\mathrm{CH}_{4}$ production. Hence, the area of validity of the $\mathrm{CH}_{4}$ prediction models that have been established in this study is limited to these conditions.

\section{Application of $\mathrm{CH}_{4}$ Prediction Models in Practice}

In the present study, we show that GC-determined MFA have a higher prediction potential for $\mathrm{CH}_{4}$ emissions than FTIR spectra. However, the GC procedure required to obtain the GC-determined MFA profile is unsuitable for routine milk recording, whereas the prediction of $\mathrm{CH}_{4}$ emission using FTIR has the potential for practical high throughput application.

Although the RPD results suggest that the GC-determined MFA-based and FTIR-based $\mathrm{CH}_{4}$ prediction models currently have limited applicability, the CCC results demonstrated that the models had at least moderate predictive ability. Potential practical applications for these models include (1) as a farm management tool, (2) to evaluate $\mathrm{CH}_{4}$ mitigation strategies, and (3) as a tool to breed for dairy cows with lower $\mathrm{CH}_{4}$ emissions (Cottle et al., 2011). When a dietary strategy is applied in practice, the proxy for $\mathrm{CH}_{4}$ emission should be able to evaluate whether $\mathrm{CH}_{4}$ emission is affected by the new dietary strategy. Therefore, within each study that had at least 2 dietary treatments, we evaluated whether the GC-determined MFA-based and FTIRbased $\mathrm{CH}_{4}$ prediction models were able to estimate the same difference in $\mathrm{CH}_{4}$ emission as measured in the climate respiration chambers, by comparing $\mathrm{CH}_{4}$ emission at 2 extreme diets (i.e., furthest apart from one another in terms of dietary composition). The results of this evaluation are shown in Table 5. In general, most $\mathrm{CH}_{4}$ prediction models predicted a difference in $\mathrm{CH}_{4}$ emission similar to the climate respiration chambers in terms of trend (i.e., increase or decrease), with a few exceptions (viz., 2 for the GC-determined MFA-based and 5 for the FTIR-based $\mathrm{CH}_{4}$ prediction models). Furthermore, estimated differences in $\mathrm{CH}_{4}$ emission between the 2 diets were generally more in line with observed differences as measured in the climate respiration chambers when the GC-determined MFA-based $\mathrm{CH}_{4}$ prediction models compared with the FTIR-based $\mathrm{CH}_{4}$ prediction models were used to estimate differences. This suggests that the FTIR-based $\mathrm{CH}_{4}$ prediction models might have less accuracy relative to the GC-determined MFA-based $\mathrm{CH}_{4}$ prediction models to evaluate the effect of forage level and quality on $\mathrm{CH}_{4}$ emission of dairy cattle.

Breeding for reduced $\mathrm{CH}_{4}$ emission can be achieved with, for example, improved productivity, increased longevity, or shorter calving interval (Bell et al., 2011) but also by breeding for actual lower enteric $\mathrm{CH}_{4}$ production (Wall et al., 2010). Several studies have 


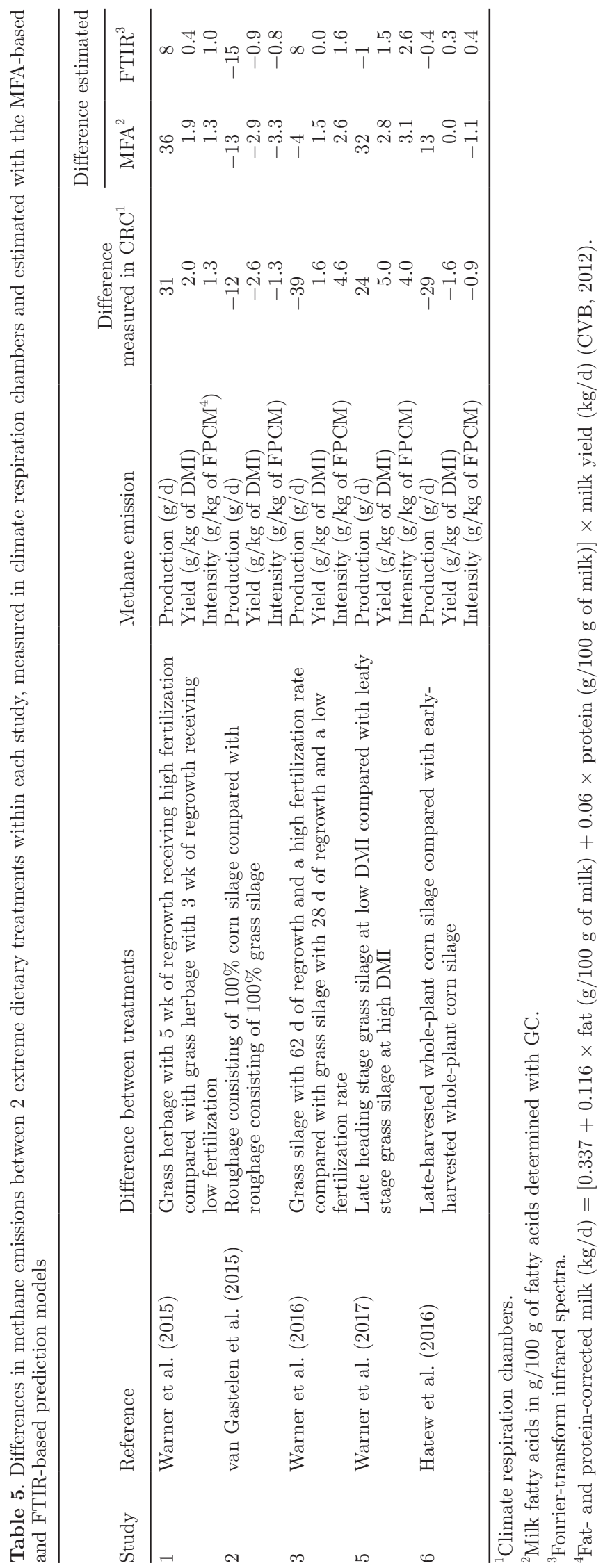

shown that $\mathrm{CH}_{4}$ emissions of dairy cows have a genetic component, with heritability ranging from 0.20 to 0.30 (e.g., De Haas et al., 2011, for predicted $\mathrm{CH}_{4}$ emission based on feed intake; Lassen and Løvendahl, 2016, for $\mathrm{CH}_{4}$ emission measured with a portable air sampler), indicating that breeding for dairy cows with lower $\mathrm{CH}_{4}$ emission may be possible. Recently, Vanlierde et al. (2016) reported that FTIR can distinguish cows with low or high daily $\mathrm{CH}_{4}$ emissions. Direct breeding for lower enteric $\mathrm{CH}_{4}$ production requires $\mathrm{CH}_{4}$ production measurements of a large number of individual dairy cows to determine the genetic component of the $\mathrm{CH}_{4}$ phenotype as well as to determine the genetic correlations of $\mathrm{CH}_{4}$ emissions with other traits. Although the feasibility needs to be assessed in actual commercial environments before implementation, the FTIR technique has the potential to assist in breeding for reduced $\mathrm{CH}_{4}$ emission because it can be used routinely to estimate $\mathrm{CH}_{4}$ on commercial dairy farms.

\section{CONCLUSIONS}

This study is the first to assess and compare the $\mathrm{CH}_{4}$ emission prediction potential of GC-determined MFA profiles and FTIR spectra based on $\mathrm{CH}_{4}$ emission data obtained in climate respiration chambers and for 3 different units of $\mathrm{CH}_{4}$ emission (viz., $\mathrm{CH}_{4}$ production, yield, and intensity). For both GC-determined MFA and FTIR, the prediction model for $\mathrm{CH}_{4}$ yield had the lowest prediction potential and the prediction model for $\mathrm{CH}_{4}$ intensity had the highest prediction potential. For all $\mathrm{CH}_{4}$ emission units, but particularly for $\mathrm{CH}_{4}$ production and yield, GC-determined MFA-based prediction models had a higher prediction potential than the FTIR-based models, and GC-determined MFA-based prediction models described a greater part of the observed variation in $\mathrm{CH}_{4}$ emission than did FTIR-based models. Results indicate that the current GC-determined MFA-based and FTIR-based $\mathrm{CH}_{4}$ prediction models have potential but limited current applicability. Additional $\mathrm{CH}_{4}$ measurements are needed to improve prediction models in terms of accuracy and robustness of both GC-determined MFA and FTIR spectra for $\mathrm{CH}_{4}$ prediction.

\section{ACKNOWLEDGMENTS}

The authors acknowledge the project "Low Emission Animal Feed," which received financial support of the Dutch Ministry of Economic Affairs (The Hague, the Netherlands), Product Board Animal Feed (Zoetermeer, the Netherlands), and the Dutch Dairy Board (Zoetermeer, the Netherlands). 


\section{REFERENCES}

Altman, D. G. 1997. Practical Statistics for Medical Research. Chapman Hall, London, UK.

Appuhamy, J. A. D. R. N., J. France, and E. Kebreab. 2016. Models for predicting enteric methane emissions from dairy cows in North America, Europe, and Australia and New Zealand. Glob. Chang. Biol. 22:3039-3056.

Bell, M. J., E. Wall, G. Russell, G. Simm, and A. W. Stott. 2011. The effect of improving cow productivity, fertility, and longevity on the global warming potential of dairy systems. J. Dairy Sci. 94:3662-3678.

Bonfatti, V., G. Di Martino, and P. Carnier. 2011. Effectiveness of mid-infrared spectroscopy for the prediction of detailed protein composition and contents of protein genetic variants of individual milk of Simmental cows. J. Dairy Sci. 94:5776-5785.

Capuano, E., J. Rademaker, H. van den Bijgaart, and S. M. van Ruth. 2014. Verification of fresh grass feeding, pasture grazing and organic farming by FTIR spectroscopy analysis of bovine milk. Food Res. Int. 60:59-65.

Castro-Montoya, J. M., N. Pieren, J. Veneman, B. De Baets, S. De Campeneere, and V. Fievez. 2017. Predictions of methane emission levels and categories based on milk fatty acid profiles from dairy cows. Animal 11:1153-1162.

Chilliard, Y., C. Martin, J. Roual, and M. Doreau. 2009. Milk fatty acids in dairy cows fed whole crude linseed, extruded linseed, or linseed oil, and their relationship with methane output. J. Dairy Sci. 92:5199-5211.

Cottle, D. J., J. V. Nolan, and S. G. Wiedemann. 2011. Ruminant enteric methane mitigation: A review. Anim. Prod. Sci. 51:491-514.

CVB 2012. Chemische Samenstellingen en Nutritionele Waarden van Voedermiddelen (in Dutch). CVB (Centraal Veevoederbureau), The Hague, the Netherlands.

De Haas, Y., J. J. Windig, M. P. L. Calus, J. Dijkstra, M. de Haan, A. Bannink, and R. F. Veerkamp. 2011. Genetic parameters for predicted methane production and potential for reducing enteric emissions through genomic selection. J. Dairy Sci. 94:6122-6134.

De Marchi, M., C. C. Fagan, C. P. O'Donnell, A. Cecchinato, R. Dal Zotto, M. Cassandro, M. Penasa, and G. Bittante. 2009. Prediction of coagulation properties, titratable acidity, and $\mathrm{pH}$ of bovine milk using mid-infrared spectroscopy. J. Dairy Sci. 92:423-432.

De Marchi, M., V. Toffanin, M. Cassandro, and M. Penasa. 2014. Invited review: Mid-infrared spectroscopy as phenotyping tool for milk traits. J. Dairy Sci. 97:1171-1186.

Dehareng, F., C. Delfosse, E. Froidmont, H. Soyeurt, C. Martin, N. Gengler, A. Vanlierde, and P. Dardenne. 2012. Potential use of milk mid-infrared spectra to predict individual methane emission of dairy cows. Animal 6:1694-1701.

Dijkstra, J., S. van Gastelen, E. C. Antunes-Fernandes, D. Warner, B. Hatew, G. Klop, S. C. Podesta, H. J. van Lingen, K. A. Hettinga, and A. Bannink. 2016. Relationships between milk fatty acid profiles and enteric methane production in dairy cattle fed grass- or grass silage-based diets. Anim. Prod. Sci. 56:541-548.

Dijkstra, J., S. M. van Zijderveld, J. A. Apajalahti, A. Bannink, W. J. J. Gerrits, J. R. Newbold, H. B. Perdok, and H. Berends. 2011 Relationships between methane production and milk fatty acid profiles in dairy cattle. Anim. Feed Sci. Technol. 166-167:590-595.

Dufour, E., P. Robert, D. Renard, and L. Llamas. 1998. Investigation of $\beta$-lactoglobulin gelation in water/ethanol solutions. Int. Dairy J. 8:87-93.

Dupuy, N., L. Duponchel, J. P. Huvenne, B. Sombret, and P. Legrand. 1996. Classification of edible fats and oils by principal component analysis of Fourier transform infrared spectra. Food Chem. $57: 245-251$.

Ellis, J. L., J. Dijkstra, E. Kebreab, A. Bannink, N. E. Odongo, B. W. McBride, and J. France. 2008. Aspects of rumen microbiology central to mechanistic modelling of methane production in cattle. J. Agric. Sci. 146:213-233.

Etzion, Y., R. Linker, U. Cogan, and I. Shmulevich. 2004. Determination of protein concentration in raw milk by mid-infrared Fourier transform infrared/attenuated total reflectance spectroscopy. J. Dairy Sci. 87:2779-2788.

Gengler, N., H. Soyeurt, F. Dehareng, C. Bastin, F. Colinet, H. Hammami, M.-L. Vanrobays, A. Lainé, S. Vanderick, C. Grelet, A. Vanlierde, E. Froidmont, and P. Dardenne. 2016. Capitalizing on fine milk composition for breeding and management of dairy cows. J. Dairy Sci. 99:4071-4079.

Gerber, P. J., H. Steinfeld, B. Henderson, A. Mottet, C. Opio, J. Dijkman, A. Falcucci, and G. Tempio. 2013. Tackling Climate Change Through Livestock-A Global Assessment of Emissions and Mitigation Opportunities. Food Agric. Org. United Nations (FAO), Rome, Italy.

Hammond, K. J., L. A. Crompton, A. Bannink, J. Dijkstra, D. R. Yáñez-Ruiz, P. O'Kiely, E. Kebreab, M. A. Eugène, Z. Yu, K. J. Shingfield, A. Schwarm, A. N. Hristov, and C. K. Reynolds. 2016. Review of current in vivo measurement techniques for quantifying enteric methane emission from ruminants. Anim. Feed Sci. Technol. 219:13-30.

Hashimoto, A., and T. Kameoka. 2008. Application of infrared spectroscopy to biochemical, food, and agricultural processes. Appl. Spectrosc. Rev. 43:416-451.

Hatew, B., A. Bannink, H. van Laar, L. H. de Jonge, and J. Dijkstra. 2016. Increasing harvest maturity of whole-plant corn silage reduced methane emission of lactating dairy cows. J. Dairy Sci. 99:354-368.

International Organization for Standardization. 2007. ISO 22662:2007 (IDF 198:2007). Milk and milk products -Determination of lactose content by high-performance liquid chromatography (Reference method). Int. Org. Standard., Geneva, Switzerland.

International Organization for Standardization. 2010. ISO 1211:2010. Milk - Determination of fat content-Gravimetric method (Reference method). Int. Org. Standard., Geneva, Switzerland.

International Organization for Standardization. 2013. ISO 9622:2013. Milk and liquid milk products - Guidelines for the application of mid-infrared spectrometry. Int. Org. Standard., Geneva, Switzerland.

International Organization for Standardization. 2014. ISO 89681:2014. Milk and milk products-Determination of nitrogen content-Part 1: Kjeldahl principle and crude protein calculation. Int. Org. Standard., Geneva, Switzerland.

Klop, G., J. Dijkstra, K. Dieho, W. H. Hendriks, and A. Bannink. 2017. Enteric methane production in lactating dairy cows with continuous feeding of essential oils or rotational feeding of essential oils and lauric acid. J. Dairy Sci. 100:3563-3575.

Klop, G., B. Hatew, A. Bannink, and J. Dijkstra. 2016. Feeding nitrate and docosahexaenoic acid affects enteric methane production and milk fatty acid composition in lactating dairy cows. J. Dairy Sci. 99:1161-1172.

Knapp, J. R., G. L. Laur, P. A. Vadas, W. P. Weiss, and J. M. Tricarico. 2014. Invited review: Enteric methane in dairy cattle production: Quantifying the opportunities and impact of reducing emissions. J. Dairy Sci. 97:3231-3261.

Lassen, J., and P. Løvendahl. 2016. Heritability estimates for enteric methane emissions from Holstein cattle measured using noninvasive methods. J. Dairy Sci. 99:1959-1967.

Lin, L. I. K. 1989. A concordance correlation coefficient to evaluate reproducibility. Biometrics 45:255-268.

Manley, M. 2014. Near-infrared spectroscopy and hyperspectral imaging: Non-destructive analysis of biological materials. Chem. Soc. Rev. 43:8200-8214.

McParland, S., G. Banos, E. Wall, M. P. Coffey, H. Soyeurt, R. F. Veerkamp, and D. P. Berry. 2011. The use of mid-infrared spectrometry to predict body energy status of Holstein cows. J. Dairy Sci. 94:3651-3661.

McQueen, D. H., R. Wilson, A. Kinnunen, and E. P. Jensen. 1995. Comparison of two infrared spectroscopic methods for cheese analysis. Talanta 42:2007-2015.

Mohammed, R., S. M. McGinn, and K. A. Beauchemin. 2011. Prediction of enteric methane output from milk fatty acid concentrations and rumen fermentation parameters in dairy cows fed sunflower, flax, or canola seeds. J. Dairy Sci. 94:6057-6068. 
Negussie, E., Y. de Haas, F. Dehareng, R. Dewhurst, J. Dijkstra, N. Gengler, D. P. Morgavi, H. Soyeurt, S. van Gastelen, T. Yan, and F. Biscarini. 2017. Invited review: Large-scale indirect measurements for enteric methane emissions in dairy cattle: A review of proxies and their potential for use in management and breeding decisions. J. Dairy Sci. 100:2433-2453.

Osborne, B. G., and T. Fearn. 1986. Near Infrared Spectroscopy in Food Analysis. Longman, Harlow, UK.

Rico, D. E., P. Y. Chouinard, F. Hassanat, C. Benchaar, and R. Gervais. 2016. Prediction of enteric methane emissions from Holstein dairy cows fed various forage sources. Animal 10:203-211.

Rodriguez, J. D., A. Pérez, and J. A. Lozano. 2010. Sensitivity analysis of $\mathrm{k}$-fold cross validation in prediction error estimation. IEEE Trans. Pattern Anal. Mach. Intell. 32:569-575.

Rutten, M. J. M., H. Bovenhuis, K. A. Hettinga, H. J. F. van Valenberg, and J. A. M. van Arendonk. 2009. Predicting bovine milk fat composition using infrared spectroscopy based on milk samples collected in winter and summer. J. Dairy Sci. 92:6202-6209.

Safar, M., D. Bertrand, P. Roberts, M. F. Devaux, and C. Genot. 1994. Characterization of edible oils, butters and margarines by Fourier transform infrared spectroscopy with attenuated total reflectance. J. Am. Oil Chem. Soc. 71:371.

Savitzky, A., and M. J. E. Golay. 1964. Smoothing and differentiation of data by simplified least squares procedures. Anal. Chem. 36:1627-1638.

Shetty, N., G. Difford, J. Lassen, P. Løvendahl, and A. J. Buitenhuis. 2017. Predicting methane emissions of lactating Danish Holstein cows using Fourier transform mid-infrared spectroscopy of milk. J. Dairy Sci. 100:9052-9060.

Soyeurt, H., F. Dehareng, N. Gengler, S. McParland, E. Wall, D. P. Berry, M. Coffey, and P. Dardenne. 2011. Mid-infrared prediction of bovine milk fatty acids across multiple breeds, production systems, and countries. J. Dairy Sci. 94:1657-1667.

van Gastelen, S., E. C. Antunes-Fernandes, K. A. Hettinga, and J. Dijkstra. 2017a. Relationships between methane emission of Holstein Friesian dairy cows and fatty acids, volatile metabolites and nonvolatile metabolites in milk. Animal 11:1539-1548.

van Gastelen, S., E. C. Antunes-Fernandes, K. A. Hettinga, G. Klop, S. J. J. Alferink, W. H. Hendriks, and J. Dijkstra. 2015. Enteric methane production, rumen volatile fatty acid concentrations, and milk fatty acid composition in lactating Holstein-Friesian cows fed grass silage- or corn silage-based diets. J. Dairy Sci. 98:1915-1927.

van Gastelen, S., and J. Dijkstra. 2016. Prediction of methane emission from lactating dairy cows using milk fatty acids and midinfrared spectroscopy. J. Sci. Food Agric. 96:3963-3968.

van Gastelen, S., M. H. P. W. Visker, J. E. Edwards, E. C. AntunesFernandes, K. A. Hettinga, S. J. J. Alferink, W. H. Hendriks, H. Bovenhuis, H. Smidt, and J. Dijkstra. 2017b. Linseed oil and DGAT1 K232A polymorphism: Effects on methane emission, energy and $\mathrm{N}$ metabolism, lactation performance, ruminal fermentation, and rumen microbial composition of Holstein-Friesian cows. J. Dairy Sci. 100:8939-8957.

van Knegsel, A. T. M., S. G. A. van der Drift, M. Horneman, A. P. W. de Roos, B. Kemp, and E. A. M. Graat. 2010. Short communication: Ketone body concentration in milk determined by Fourier transform infrared spectroscopy: Value for the detection of hyperketonemia in dairy cows. J. Dairy Sci. 93:3065-3069.

van Lingen, H. J., L. A. Crompton, W. H. Hendriks, C. K. Reynolds, and J. Dijkstra. 2014. Meta-analysis of relationships between enteric methane yield and milk fatty acid profile in dairy cattle. J. Dairy Sci. 97:7115-7132.

van Lingen, H. J., J. E. Edwards, J. D. Vaidya, S. van Gastelen, E. Saccenti, B. van den Bogert, A. Bannink, H. Smidt, C. M. Plugge, and J. Dijkstra. 2017. Diurnal dynamics of gaseous and dissolved metabolites and microbiota composition in the bovine rumen. Front. Microbiol. 8:425.

Vanlierde, A., M. L. Vanrobays, F. Dehareng, E. Froidmont, H. Soyeurt, S. McParland, E. Lewis, M. H. Deighton, F. Grandl, M. Kreuzer, B. Grendler, P. Dardenne, and N. Gengler. 2015. Hot topic: Innovative lactation-stage-dependent prediction of methane emissions from milk mid-infrared spectra. J. Dairy Sci. 98:57405747.

Vanlierde, A., M. L. Vanrobays, N. Gengler, P. Dardenne, E. Froidmont, H. Soyeurt, S. McParland, E. Lewis, M. H. Deighton, M. Mathot, and F. Dehareng. 2016. Milk mid-infrared spectra enable prediction of lactation-stage dependent methane emissions of dairy cattle within routine population-scale milk recording schemes. Anim. Prod. Sci. 56:258-264.

Vanrobays, M.-L., C. Bastin, J. Vandenplas, H. Hammami, H. Soyeurt, A. Vanlierde, F. Dehareng, E. Froidmont, and N. Gengler. 2016. Changes throughout lactation in phenotypic and genetic correlations between methane emissions and milk fatty acid contents predicted from milk mid-infrared spectra. J. Dairy Sci. 99:7247-7260.

Vlaeminck, B., V. Fievez, A. R. J. Cabrita, A. J. M. Fonseca, and R. J. Dewhurst. 2006. Factors affecting odd- and branched-chain fatty acids in milk: A review. Anim. Feed Sci. Technol. 131:389-417.

Wall, E., G. Simm, and D. Moran. 2010. Developing breeding schemes to assist mitigation of greenhouse gas emissions. Animal 4:366-376.

Warner, D., A. Bannink, B. Hatew, H. van Laar, and J. Dijkstra. 2017. Effects of grass silage quality and level of feed intake on enteric methane production in lactating dairy cows. J. Anim. Sci. 95:3687-3700.

Warner, D., B. Hatew, S. C. Podesta, G. Klop, S. van Gastelen, H. van Laar, J. Dijkstra, and A. Bannink. 2016. Effects of nitrogen fertilisation rate and maturity of grass silage on methane emission by lactating dairy cows. Animal 10:34-43.

Warner, D., S. C. Podesta, B. Hatew, G. Klop, H. van Laar, A. Bannink, and J. Dijkstra. 2015. Effect of nitrogen fertilization rate and regrowth interval of grass herbage on methane emission of zerograzing lactating dairy cows. J. Dairy Sci. 98:3383-3393.

Williams, P. 2014. The RPD statistic: A tutorial note. NIR News $25: 22-26$.

Williams, P. C., and D. C. Sobering. 1993. Comparison of commercial near infrared transmittance and reflectance instruments for the analysis of whole grains and seeds. J. Near Infrared Spectrosc. 1:25-33.

Yang, H., and J. Irudayaraj. 2000. Characterization of semisolid fats and edible oils by Fourier transform infrared photoacoustic spectroscopy. J. Am. Oil Chem. Soc. 77:291-295. 